Portland State University

PDXScholar

\title{
An Alienation Measurement and Observed Behavior: A Study of Forty-Two Male Seniors in a Technical High School
}

Jack Leo Terzenbach

Portland State University

Follow this and additional works at: https://pdxscholar.library.pdx.edu/open_access_etds

Digitadrt of the Educational Sociology Commons, Place and Environment Commons, and the Social Peyamoregy and Interaction Commons Newtorks know how access to this document benefits you. Logo

\section{Recommended Citation}

Terzenbach, Jack Leo, "An Alienation Measurement and Observed Behavior: A Study of Forty-Two Male Seniors in a Technical High School" (1972). Dissertations and Theses. Paper 1604.

https://doi.org/10.15760/etd.1603

This Thesis is brought to you for free and open access. It has been accepted for inclusion in Dissertations and Theses by an authorized administrator of PDXScholar. Please contact us if we can make this document more accessible: pdxscholar@pdx.edu. 
AN ABSTRACT OF THE THESIS OF Jack L. Terzenbach for the degree of Master of Social Work presented May 18, 1972.

Title: An Alienation Measurement and Observed Behavior: A Study of Forty-two Male Seniors in a Technical High School.

APPROVED BY MEMBERS OF THE THESIS COMMITTEE:

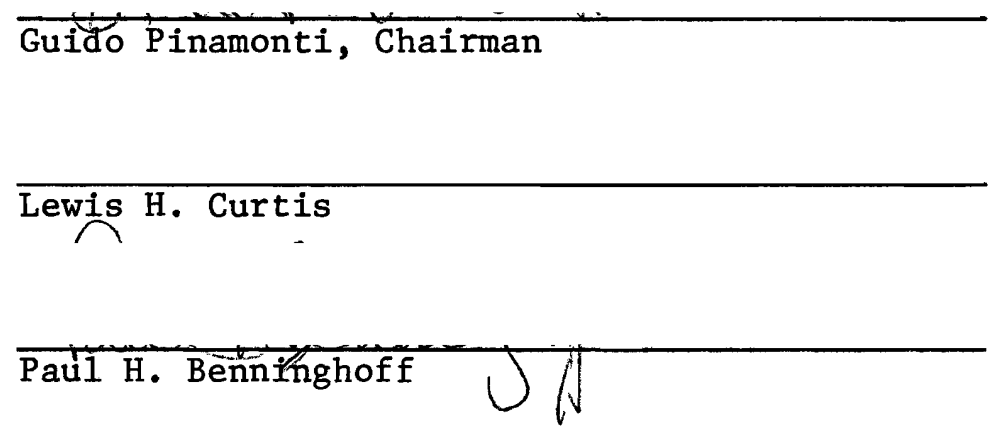

The study examined the relationships between subjects' degree of alienation and descriptions of their behaviors. The subjects were 42 male, senior students at Benson Polytechnic High School who attended one of two required social science classes. Benson High School is an all male, technical high school which admits students from all parts of the City of Portland, Oregon. Alienation was defined as a syndrome of feelings consisting of apathy, distrust, pessimism, cynicism, and emotional distance. The degree of subjects' alienation, as defined, was measured by the Multiple Alienation Measure devised by Dr. Laurence J. Gould. Subjects' were thereby divided into three alienation groups; high alienation, moderate alienation, and low alienation. School personnel described subjects' behaviors by selection of descriptions from a questionnaire. Two counselors described subjects' engagement in 
extra-curricular activities in terms of (1) whether they were inactive, (2) active in sports or other extra-curricular activities only, or (3) active in both sports and other extra-curricular activities. Two teachers described subjects' involvement in their social science classes in terms of (1) whether they did we11 in assigned work and did extra work, (2) did well in assigned work only, (3) or did not do we11 in assigned work. The vice-principal described the conduct of subjects in terms of whether they were (1) well behaved, (2) had problems that were handled in the classroom, (3) had probems for which they were sent to the office and, perhaps, suspended once, or (4) had problems for which they had been suspended more than once.

A positive relationship was found between the degree of alienation and the degree of conduct problems as described by the vice-principal. This relationship was significant at the .05 level by a chi-square test. No relationships were found between the degree of alienation and extracurricular activities and behavior in social science classes. However, the alienated were described by teachers as either unmotivated or very motivated students. A tendency for the alienated to be described by the extreme statements concerning activities also appeared.

The findings of the study were interpreted by a theory developed in the introduction and in the concluding chapter of the thesis. The theory presented the alienation process as an interaction of the individual and his social world in which difficulties in the formation of identity result in a tension expressed by the feelings measured as alienation by the Multiple Alienation Measure. The tension gives rise to intense and, of ten extreme attempts to explore the social world in 
order to establish identity, or to a lapse into apathy. The greater conduct problems of the highly alienated was seen as a result of the intense activity of the search for identity. The highly alienated subjects' tendency to be either very good or poor students was seen as an intense, and therefore, extreme drive to resolve alienation tension by embracing the student role or by rejecting it. 
AN AIIENATION MEASUREMENT AND OBSERVED BEHAVTOR:

A STUDY OF EORTY-TWO MALE SENIORS

IN A TECHNTCA F. FGH SCHOOL

by

JACK IEO TERZENBACH

A thesis subnitted in partiej fulfilinerit of the requirerients for the degree of

MASTER GF SOCTAI WORK

Porthand State Untuezetify

1972 
TO THE OFFICE OF GRADUATE STUDIES:

The members of the Committee approve the thesis of Jack L. Terzenbach presented May 18, 1972.

Guido Pinamonti, Chairman
Lewis H. Curtis

APPRNVFR :

Gordon Heaff, Dean, School of Strial Work

David T. Clark, Dean of Graduate Studies

May 18, 1972 
TABIS OF CONTENTS

PAGE

ACKNONLEDGERETS , . . . . . . . . . . . . . . . .

CHAPTER

I INTRODUCTION AND RETIEW OF LITERATURE , . . . . "

Alenation and Society........."...

Alienation and the Individual . . ....."

Alienation as the Individual State

and Parts of the Provess

Alienation as an Individuei

state: A Syndrone

Factors Commony Associated with Alienation .

Anomie

Mental Illness

Theory and riscussfor,....,$\ldots . . .24$

II METHODCLOGY . . . . . . . . . . . . . . 28

The High Sorool . . . . .......... 31

Selection of Subjects . . . . . . . . . . 31

Selection of School Persomei . . . . . . . 33

Advantages and loe of the low thple

Alienation Measure.............

bevelopment and Usis of the Hawhy

Questornatre ............... 
Conduet

Engagement in Activities

Academic Approach

Sumary of Stroy Method . . . . . . . . . 42 III FINDINGS ...................... 44

Distribution of MAM Scores .........." 45

Engagement in Activitios ............4 46

Asademic Approach . . . . . . . . . . . 48

Conduct.................... 51

Sample Limitations ............... 53

Sumary of Findings . . . . . . . . . . . . 53

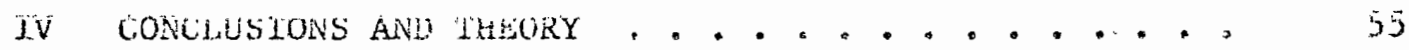

Conduct..................... 62

Academic Approach .............. 64

Engagement in Activities ........... 65

Sumrary .................. 66

FEELRENCES CTTED . . .................... . . . . . 68

APPENDTX A. .......................... 72

APPEADTX B .......................... 74

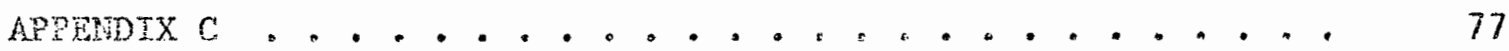




\section{ACXNOWLEDGTERNTS}

The writer is indebted to a number of people wino have extended their tine and tajents to facilitate his efforts to produce the study. DE. Martha Ozawa, aithcugh not a member of the writer's comittee, offered useful advisement concerning the presentacion of findings. The ready cooperation and help of Harold H. Andersen, primetpai of Benson High School, was very appreciated. Several members of the staft at Benson have spent a number of hours, taken from their busy days, to participate in the study. They were: Mary E. Gilnore, teacher, Willtam B. Hryciw, teacher, Florence Meagher, counselor, Arnold R. Cray, counselor, and Boul g. Penninghofe, ricemprincipal, last, but not least, the writer owes thanks to the students of Mrs. Gilmore's and Hx. Hryciw's social science classes who participated in the study as subjects. 


\section{LIST OF TABLES AND FIGURE}

TABLE

PAGE

I. Alienation and Fngagenent in Activities as Described by Counselors . . . . . . . . . . . . .

II Academic Approach in Social Sciences Class as Described by Teachers . . . . . . . . . . . . *

II Academic Approach of Uninvolved Subjects . . . .

IV Conduct as Described by the Vice-Principal . . . .

$\checkmark$ Conduct of Inactive Subjects . . . . . . . . .

FIGURE

1 Distribution of MAM Scores of the 42 Subjects.... 


\section{CHAPTER I}

\section{INTRONUCTION AND GEVIEF OF LTTERATURE}

Recognition of the existence of processes of alienation has been a part of man's efforts to explain and understand himself and his affairs since the beginning of witten history. The story of Adam and Eve (Gensis Cn. 3) is an account of alienation. Adan and Eve, because they had sinaed, were separated from their world. Sinco they falt stame for their sin, they were also separated within theinselves. They could no longer accept themselves as harmonicus, whole beings at one with paradise and God. They had acquired knowedge, and they were condemted to live by their cwn efforts, thet is, by their autonomy, in another world that was relatively barren and insensitive to their reeds. Applied to the fall of Adam and Eve, then, the word "elienation" would nean a state in which one is cut of from his world and separated within hinseif through shame. This writer believes that a sense of the possibility of alienation has been part of Christianity for many centuries. The nedieval catholic Church, becavse wt was able to draw men rogether in corporate liwhig, or to aliente them from the corporate, religious commity, had greet power in its use of excominication.

A sense of alienation has also been part of the strugale of philosophero to understand man and his affairs. For exanple, liegel, pessintsteal1y, viewed alienation as an fnevitable outcone of sociajiwation. He feit that socialtatton must derach men frou thetr ow 
natures and the world of nature $(1, p .29)$. On the other hand, Soren Kierkegara (2, F.142), although he was influenced by Hegel. invisioned a state of existence in which a man could be intinately connected wits his world, yet live subjectiveiy, through his passions, and at one with his own nature. However, Kierkegaard (3, pp. 146-154) recognized and emphasized the individual's experience of alienation as an inner despair. He wrote of what he called the "despair at not willings to be one-self" which he called a "sickness unto death." In this sickness, there ore no hopes for life or death. Kierkegaard's views suggest that the individual can lose hope in the possibility that, through expressIng what he is, he can live a iffe that is congruent with his worlu. This witer feels that Hegel and Kierkegazd are juportant in any

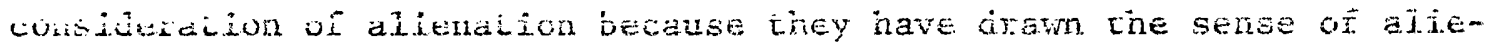
nation out of the realn of mysticien by demonstrating that alienation is a function of the relationship beween the individual and his anvironment. Alienation, considered as a function of the relationship between the individuai and his environnent, can be conceptualized as sone state of the individual, sone state of the envixonment, or as the entive process of action aid reaction between the wo.

The motern sciences have often relied on the incultions of reld-n gion and philosophy in the projection of theory and have often confirmed the intutons of the past. The task of science tis to produce theories concentrg such conepts as aliention and to define parts of the conm cept in such a way that those paris can be empitically reasured. Masuremen, in tum can confin or cast douts won the theory. Judg-

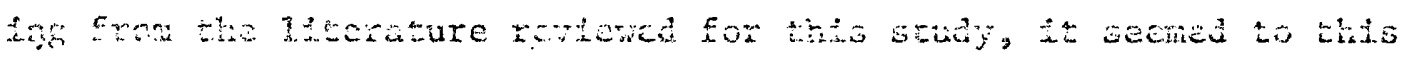


viter that the authors of definitions of alienation have not reached a state of agreement that can enable them to coamunicate clearly with one another in the secure knowledge that they are using the texi alieration in the same sense. Keniston (4, p.389) attributed this lack of agreerient to the fact that the term alienation, ambiguous to begin with, has become a fashionable concept and, therefore, has been emptied of specific meaning. Keniston felt it necessary to remind his reaciess that he was using the term according to his own peculiar meaning. He seened to accept most definitions of alienation as ifgitimate within the context of their use. Apparently, he accepted the tern aijenation as referring to the whole process of alienation taing place in the relatinship between the individual and his enviroment.

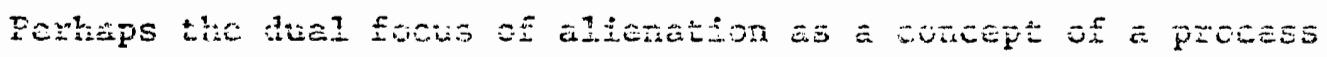
taking place between the fuciviual and iis environment, with the nany aspects implied, has been partianly the cause of the great profusion of definitions. Ailenation as a process inplies an agent that tends to cause feelings within the individual to be felt toward something or someone ejse. This multiple-faceted process can allow many inferpretacions when lised to develop social-psychological theories of bumen behavior. Definitions have varied according to whether the social contitions, the inner states of individuads, or the process of alien ation, or sone conbinations of facets of these have been the focuses of the particular author.

Since no one specific definition of alienation has become widely accepted as the sole definition, each empirical sudy of some facet of the comont should tegin by sxamining the literature on altaration in 
order to place its own definition in perspective with concepts of alienation that heve been used either in thecry development or in other empirical studies. In order to place the definition used in this study into a perspective with the literature on the subject, the literature reviewed was divided into two parts. First, there vere those authors Who emphasize the social forces involved in the alienation process. Second, were those authors and researchers who stress the part of the individual in the process. The latter group were divided into two sub-groups according to whether the authors view alienation as a syndrome of feelings and attitudes, or whetrier they include in their definjtion parts of the procese taking place cutside of the individual. The development of the definition of alienation used by Gould (5, pp.

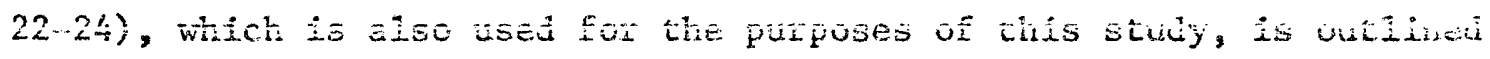
in Its relationship to the literature reviewed and its advartages to this study. Also, some concepts that have been associated with alienation are discussed.

\section{ALIENATION AND SOCTETY}

The tine and space linitarions of this study have made it necessary to limit the number of evthors reviewed. Anong the autuors who have viemed alienation from a societal perspective, the rames of Harz and Fromu appear most of cen in the 1iferature. Keniston has done more recent and comprehensive work and, at present, appears to be the leading author on the subject of arienation.

Eollowing the work of Hegel, it remaines for Karl Marx to fntroducs tho term aliopation into a cosologieal context. Narr (6, p.498) 
viewed the capitalist mode of labor as a force creating self-estrangenent In the workex. Those who own the products of labor control labor itself. Therefore "... the object which labour produces--labour's product-confronts it as something alien, as a power independent of the producer." Marx seens to have believed that, in order for the worker to feel his uwn creative powers as part of hinself, he needed to own the products of ixis work. When the worker no longer controls his rieans and his products, he is alienated from some vital aspects of himself, that is, his productive capacities and their potential to integrate rim, through his own character and abilities, with his society. Marx $(6, p .498)$ speaks of "... appropriation as estrangement, as alienation." Like Hegel, Marn saw in social forces, particularly in industrial

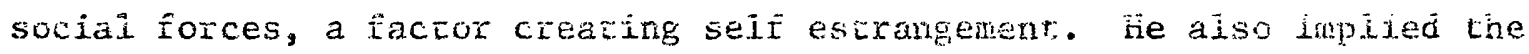
concept of powerlessness, since, in a capitalist society, the worker could not adequately control the products of his labour, nor the means, and was, therefore, powerless to use his economic capacities to integrate himself into his socjety. However, since Mam's focus was on the historical forces of economics, he dio not elaborate upon the psychom logicel aspects of estrangenent, despair, and powerlessness as did other 2uthors.

From's view of the social causes of alienaticn were similar to those of Marx in sone respects, but he drev then from the wider concept of indusirial society rather than from the narrow concept of the capitalist mote of production. From (7, pp.111-145) sav big government as a power over men that has somehow gone beyond the ability of men to

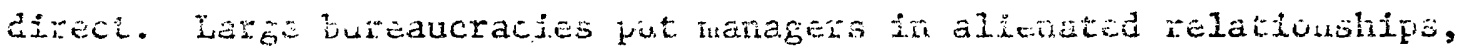


rather than personal ralationships, to the many whom they influence. Ownerstip of the means of production is no ionger a direct expression of the creative ability of the owner, but is simply a matter of owning symbols of production. pieces of papex. Comnodities are purchased, not. For the personal pleasure of their use, but for the pleasure of possession itself. Leisure time, also, is not an expression of one's own creative powers, but is a matter of spectatorship and consumption. One's reletionship to oneself is as a thing to be enployed, and self evaluation comes to depend on the "fickle judgnent of the narket." And, lastly, Froum saw modern authority ds being anonynous. It lacks the overt quality that makes possible the development of ar individuals sense of self striggling with the persons and the values supported by authority. Kendiston (4, pp.103-340) saw the problem or the development of a self in a slightly different light. To Kenjeton, rapid and unrestrained techological and social. change were a central condition of the lives of industrial peoples. Keniston believed that change lends to authority a quality of irrelevance, because rapid change deprives the individual of a relevant: past, with its support of traditional authority, against which to rebel or through which he nay seek improvements of society. Consequentiy, change deprives the individual of much that could provide lint with personal ains and identity. Change nay cause the individual. to experience life as a chaos, racher than as a progression. Keniston feit that change creates difficulties for individuals in the process of takjne roje models and achieving identity. As a result, nany individwajs becone orienced to the present and a hedonistic approach to life. 
Also, it would appear that Keniston (h, po.219-220) sas a terdency toward the fragmentation of life in the loss of comminty and the increasing specialization of social and econonic roles that have effected drastic changes in the "psychology of self-ulefinition." The shift of values from "devotion and reverence" to "proiuction, innovation and selling" that has come with industrial society, tends to destroy an individual's sense of belonging to an order that can give continuity to 1ife. In fact, in Keniston's view, production placed cognition above passion as a dominant social value. Fassion tiust be dissociated and expressed through "outlets" that are considered in tems of social usefulness, neither productive nor creative. The resulting compartmentalization also has adverse consequerces to the maintenance of

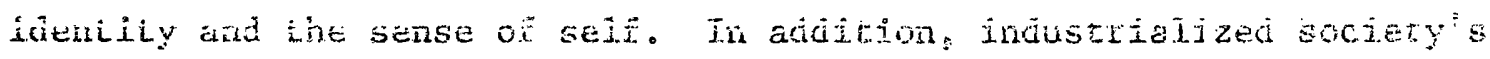
lack of a shared Iyth creates a situation in which the indivianal projects his aims in relative isolation, thus risking the possibility that he will not find social means or support to work out his eims and a consistent identity.

Two other auchors should be discussed briefly because their yiews support and enlarge upon the type of theory expressed by Keniston and Frome Jules henry (8), imputed to our society a set of sociaj. forces growing from its piacement of profit naking and prodict seiting in the positions of primary values. Henry's view of these domingat values resented Keniston's assercion that our present values are deternined by producton, innovetion, and selling, and they resembled Fromin's feeling thot our nodes of omership and consmption have ar alienating

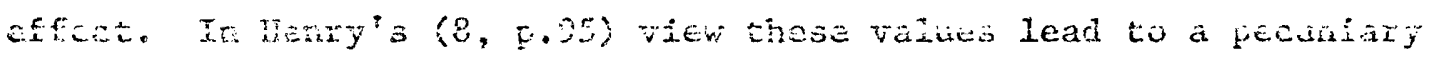


psychology that denied the individual the means of integrating a unified self with his culrure. As a result, the individual tends to be ".. alienated fron the self," $(8,9.292)$. Alienation, in Henry"s (8, f.292) theory, was accompanied by feelings oi inadequacy and weak. ego structures.

Helen Lynd $(9, \mathrm{p} .57)$, who spoke of a concept of Ehame, may have cffered some understanding of how feelings of alienation are generated. She defined siname as the expertence acoruing fron a sudden, unexpected exposure cf a discrepancy between one's self image and the ccnditions of one's environment. This experience, she asserted, produces alienation. The theme of disjuncture between the individual's development, a theme set forward by Keniston, Fromm, and Henry, was for Lync, accompanied by a moment to monert experience of pain that produces alienation.

The authors reviewed above may differ in the importance they assign to the various socjal forces in an industrial society hich produce alienation. For examples, Marx emphasized the capitalist mode of production, and From focused on more diffuse economic forces, while Keniston stressed economic and social forces. However, these authors seened to agree that industrial sccieties are failing to meet the needs of individuals with a vilingness to negotjate secure and lastim terns of existence that parmit then to integrate their whole persons into the Ébric of their societies, and, chereby, remain intact within thenselves ans cunguent with their socicties. They appeared to be saying that the individual canrot adequatoiy project hinself as he is into the processes of work and production, of ownership and consumption, and of the requitenenta of authority, beverse bese processes have becone 
unavailable to his personai influence. In sumary, they would contend that the development and matntenance of identity ${ }^{1}$ (a sense of integrity that is congruent with the cultural and social envircninent) is made difficult by nany socfal forces in industrial society.

Keniston (4, p.389) noced the recent increased interest in concepts of alienation. The fact that various concepts of alienation have received increased attention during the past few decades raises the queston of whether or not the social forces leading to aljenation have become stronger in our modern, industrial societies than in past societies. A few authors addressed themselves to this question. Dean (10, p.185) quoted Gouldner who felt that alieration is growing becalise technological society is diminishing the "... range of choice oper to the oriinary indiviculu, whise] the area ot discretion available to him, is declining." Moreover, Pappenhein (11, p.15) believed that the growth of expressions of alienation spring from "... the basic direction of our period and i.ts social structure." papperhein, (11, p.16) realistically stated that the social forces of alienation have existed in all ages, but that they have become intensified in a technological

$I_{\text {Erikson }}(12$, p.50) defines ego identjiy as "... The awareness of the fact that there is a seif-sameness and continuity to the ego's synthesizing methots, the style of me's indivinulity and that this style coincties bith the sameness and continuity of one's meaning for significant others in the imnediate commity." Thus, Erikson limits the idea of continuity with ouhers to those of the immediate connunity. Trib writer's use of the word identity would include Erikson's definition and add the individual's awareness of his continuicy with the values of his society, whether the awareness of those values comea to the individual. through direct experience with an immediate comming or through netional rass nedia, or through the experience of nobility, or otter meane made posstble and necessary in an industrial society. 
society. It seemed logical to this writer, that if alienation is produced by rapid change and by hindrances to the expression of self through social processes, then alienation will assume a greater importance in a technological society than it has in past, wore corporate, and simpler types of societies. In the latter societies, the self was in a more direct and clear relationship to the institutions and traditions through which it was socialized and through which it iived. Industrialization has increased the autonomy of the individual at the price of rediced means by wich he can integrate himself with his society. 2

\section{ALIENATION AIND THE INDIVIDUAL}

The aforementioned authors did not based their writings on empirical study, but rather they developed social theories of the social causes of alienation. Kensiston, in thet he dealt with both theory and empirical study, was, perhaps, the one exception.

There are, however, a large number of authors who have been primarily concerned with the question of the individual's experience of alienation and its situational and behavioral cutcomes. These authors can be further divided according to whether they view alienation as the

$2_{\text {Tofflex }}(13, \mathrm{p} .17)$, although he does not concern hinseif with the literature of alienation, also notes thet industrial, technological. devejopments have broight unpreridented changes in man's existence. He states that "We no longer "feel" life as men did in the past. Ano this is the witingte difference, the distinction that separates the truly contemprary man fron all others." Tofluer feels that technological man experierces his world differently and that this affects his way of relating to "... other paople, to things, to the entire uaiverse of fost, ant and values." Such relationships, in Toffler's view, now come about in a conteyt of rangience as a result of repid change. 
part of the alienation process manifested in the foelings and attitudes of the indfydual, or whether they include, as alienation, other parts of the alienation process, such as the behavioral or situational. results of feelings of alievation.

It was the writer's opinion that those efforts that resulted in defintions of alienation as syndromes, that is, sets of attitudes and feelings aione, were best suited to the scientific exploration of the alienation process. The alienation symome concept serves to fix a point of demonstrable realicy and a point of departure for expioration of the empirical. nature of the other parts of the process. Definitions that draw on the assumed relationships between feelings of alienation and aspects of alienation exterral to the individual. tend to introduce

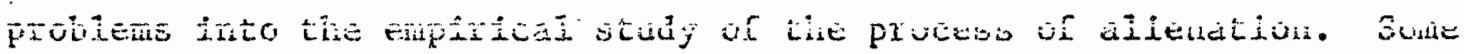
of these problems are discussec in the folloming subsection.

\section{A.ienation as the Individual state and Parts of the Process}

As mentioned above, some authors treated the subject of the alienated individual as if his alieration incluced one or more of the facets of the process taking place between the individual and his society. As an exampje, Hajhà (14, p.758) defined alienation as: ...an individuai's feeling of uncasiness or disconfort which reflects his exclusion or self-exclustor from social and cui-. tural participation.

Hajda included in his definitior, not only the feelings of alienation, but also the aspects of the process of alienation, such as selfm exclusion and socially causer exclusion from social participation. Similariy, Broming et. a1. (15, p.780), ir criticizing Secnan's work, 
stated that Seeman's types of alfenation should include stages of social exclusion. Rogers (1.6, pp.11-14) treated alienation as the state of an individual that can be inferred from his self-exciusion fiom social participation and his rejection of values through protest or: subculture membership. 3

The problems inherent in definitions of alienation which include parts of the process can be illustrated by an experience related by Keniston (4, p.3). In his book, The Uncommitted, Keniston, like Rogers, assumed that students' unrest and their rejection of scciety were indications that those who engaged in protest activities were alienated in the sense of possessing feelings and attitudes of alienation. However, after studying a number of such students, Keniston (ii, p.34ij conciuáed thar he was:

-..inclined to see most student protest not as a manifestation of alienation (as I hare used the term, ) but rather of commitment to the very values the alienated students reject.

Thus, he founc that he could not empirically correlate rejection of social participation as evidenced by his stury subjects with feelings and attitudes of alienation. Such a correlation is assumed ir the definitions of Brown, Hajda and Rogers. Keniston's study suggested that such defindtions nay fail to accurately describe a reality with can be tested. Behaviors atrd outcomes of behavior may not correlace with the feelings and attitudes of alienation, nor will the feelings and

3 Byles (18, p.104) presents an interesting approach to alienation. Je constrused an alienation-integration scale based on degrees of affiliarion with such Institutions as the failily, the school, the churb, recreation, employment, and the jaw Apparentiy, to byles, alienation is a prosess involving the facet of disaffiliation. 
attitudes of alienation necesarily correlate rith specific behaviors and outcones of behavior which are populariy associated with azienation. Therefore, definitions that include assumed correlations may tend to confuse and lead to an inaccurate description of the process of alienation as it exists in reality,

The authors reviewed below avoided this problen by limiting their concept of alienation. For these authors, the word "alienation" has come to mean sets of feelings and attitudes that have been empirically demonstrated to exist in certain individuals. Other authors have made assumptions about the behaviors and outcomes of the alienation process, without measuring aijenation in terms of their own definitions. The authors discussed below, however, have used definitions which enaibie then co measure aitenation and correlatiors or elienation. These authors have developed definitions of alienation that can be understood as syndromes, sets of feelings that are symptous of the existence of a state of alienation within the individual. Since these syndromes can be measured, assumptions about other parts of the alieriation process, such as social causes and behavioral outcomes, can be cheched against reelity.

\section{Altenation as an Individual State: A Syndrome}

Most of those who attompted to measure altenation in the individval were guided, directly or indirectly, by the theories of alienation as presented by such witers as Fege1, Marx, and Fronm. Melvir Seeuan $(13$, po.783-791) was probably the first to attenpt to extract from the Hiterature of alienation theory sone aspocts of the concept that could 
be submitted to empirical examination. Seeman developed five ways to use the term alienation. First, he derived powerlessness as the expectancy by the individual that he cannot, through his own behavior, determine the outcoine he seeks. Seeman wished to limit this aspect of alienation to expectancies in large social events anci to refrain from application of the aspect to the events of the individuel's immediate and intimate environnent. Sacond, he posited that neaninglessness refers to the expectation of the individual that adequate predjctions about outcomes cannot be made. This comes about when the individual in his own experiencing, finds that "... minimai standards for clarity in decision making are not met" (19, ficient belief system" that can be either "descriptive or normative." Irimd, he staced that nomiessness, in the individual, te a "high expectancy that socially urappoved behaviors are required to achieve given goals (19, p.788)." Eouth, he noted that isolation refexs to the individual"s tendercy to "assign low revard value to goals or beilefs that are typically highly valusd in the given society" (I9, f.799). The term isolation does not refer to a lack of social adjustment or wam friendships. Selfmestrangenent, the fifth aspect of alieration, Sechan defined as the tenderioy lo expect the value of an activity to be found in some ". . anticipated future reward, oustide of the activity itself" (10, p.790).

Following Seeman's approach, Dean (20) constructed scales of porerlensmoss, nomlessiess and isolation. He submtted a laxge number of iten atctanents to jugges, He selected fron whe statements those

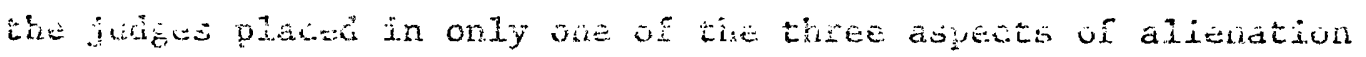


(10, p.188). Dean (20, pp.756-753) found correiations among his three scales. He also found a correlation between his scale of normlessness and Srole's scale of anonic.

Nettler (1, pp.670-677) used an approach somewhat different from Dean's. Through his examination of literature he selected that aspect of alienation termed "estrangenent from soctety" as his subject of study ( 1, p.672). He drew from popular literature and psychological literature several "descriptive models" of "estrangement from society." These were distributed to colleges and acquaintances who selected people they knew who fit the model. The selected subjects were interyiewed for the purpose of determining comon attitudes that were translated into a number of item statements of a scale neasuring aljer:-

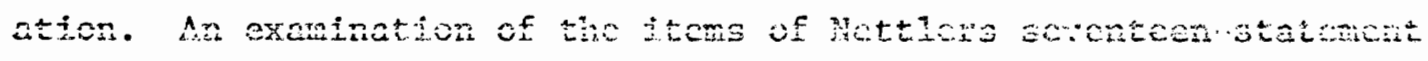
scale and Gould's (3) Multiple Alienation Measure revealed that several of the items were remarkable similar.

Keniston (17, pp.327-328) and his colleagues developed a set of intercorrelated attitude scales. He described these scales as follows:

1. Distrust ("Expect the worst of othexs and you will avoid disappointment"); 2. Pessimism ("There is little chance of ever finding reel happiness"); 3. Avowed Hostility ("At tines, sone people make you feel like killing them"); 4. Interpersonal Alienation ("Emotional comitnents to others are usually the prelude to disappointment"): 5. Social Alienaticr ("Teamwork is the last refige of meliocrjty"); 6 . Cultural Alienation ("The idea of trying to adjust to society as it is now constituted fills ne with horror"); 7. Self-Contempt ("Any man who reaily knows himself has good canse to be horrified"); 8 . Vacillation ("I make few comiments without some reservation about the wiston of undertaking them"); 9. Subspection ("Fixst intressions canot be rejied upon; what lies berieath the surface is often utterly diffenent"); 10. Outsider ("I foer strongly how different $Y$ an from most people"); 11. instructured wniverse ('The notion that man and nature are

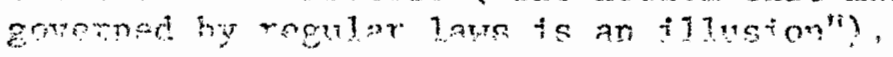


The mean scale to scaie correlation was found to be plus .47, with Distrust being the wost highly correlated with the otier scales. Keniston took the attitudes veasured by all of the scales as a definition of the "alienation synirome."

Davids $(21,22)$ created a construct of alienation consisting of the following variables: egocentricity, distrust, pessinism, anziety, and resentment. These feelings and attitudes were similar to several of Keniston's attitude scales making up the alienation syndrome.

Struening and Richardson (24, pp.76.3-776) founded their work in theory by constructing three hundred item statements suggested to them by the works of Adorno, Davids, Srole, Durkhein, From, Marx, Merton, and even Canus: novel, The Stranger. They then reduced these itens to suxty-eight stacements and used them along with concert opposites. They tested these siyty-eight statements with the following populations: patients from a ward for the criminally insane, long term male mental patients, hospitalized fenale mental patients, fnstitutionalized, delinquent juveniles, dischargeable male mental patients, college undergraduates, and adult education students. From a $68 \mathrm{x} 68$ correlation matrix, ten factors emerged. Each item showed bigh loadug on one faotor and very low or no loading on all other factors. In other wots, groups of statements, distinctly separate from one another energed from the natrix. If an indlvidual responded in one way to an item, he was bighly likely to respond similerly to the other itcms in the group of itens. One group of itene, the factor of "alienation via rejection" was characterized by statenerts of feelings of cynicism,

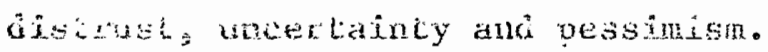


These authors took iten statenents that could describe the attitudes and feelings of alienated individuals as expected on the basis of theory. By correlating subjects' responses to such statenents, they discovered sets of feelings and attitlides that tend to occur together in the same individuals. Thus, they were able to eljminate through their research certain feelings and attitudes that appear to be irre1evant to a concept of alfenarion as it exists in the individual. Several of the researchers chose to view the sets of feelings and attitudes discovered by them as syndromes.

The various syndromes which have evolved from these studies, : : seemed to bear differences and similarities. This witer believed that the differences were part of differences in the author's views of theory and their differences in methodolngy. The sinjuaties suggosted that these authors were measuring vexy nearly the same syndrone of feelings and attitudes. Six types of feelings or attitudes appeared frequenty in the literature reviewed. Two or more authors mentioned these types of feelings as part of an alientation syndrome. They are: cynicism, distrust, uncerteinty, pessimism, egocentxicity, and resentment.

The simflatities suggested that it may be possible, through further research, to demonstrate the existence of a single syndrone whose description can be widely accepted as a definition of alienation as it exlsts in the individuil, However, at the present state of alienation research, any sudy that proposes to confine itself to atterpts to correlate other factors of the ajienation process with an alienation symrome must rake use of ar existing measure. 
For the purposes of the present study, the Multiple Alienation Measure (MAir) developed by Gould ( 5 pp.22-24) was selected for use. The development of this measure is discussed in the foliowing paragraphs.

Gould's (5, pp.22-24) work in developing the MAM was largely based on the studies done by struening and his associates. After examining existing measures of alienation, Gould chose items for his measure from three studies, including the Struening and Richardson study mentjoned above anà two other studies done by Struening. Although Gould reviewed a number of measures, Struening's work seened to have fitted his criteria best. Gould's criteria in selecting itams were as follows: face validity, derivation from factor analytical work, derivation from heterogeneous samples, measurement of non-specific central dimensions of alienation, and high loadings on major factors appearing through several studies. Gould used items from Struering's works that were comprised of factors highly related to alienation. From the jtems that fit his criteria Gould selested twenty best items to make up the Multiple Alienation Measure. ConsequentIy, Gould constructed a measure of alienation that should be valid in many widely segarated and different populations.

This witer exantned Nettler's measure of aijenation and found similarities between it and the MAM on severzi items. Gould (5, p.25) noted similarities between his MAM and scales developed by Dean and Dy Keniston. Moreover Gould (5, pp.18-19) saw his definition as being related to Seeman's work, but he felt chat he had eliminated the expectancy and cognitive racoors in favor of a definition simpiy 
describing feelings of allenation. David's construct of alienation closely approximate Gould's deffnition of alienation as a "general or core syndront consisting of feelings of possinism, cynicism, distrust, apathy and enotional distance $(5$, p.19)." Einally, considering the sources of items used by Struening and his associates, the Nari can be considered to be related to a general theory of ailenation. The toany similarities between the MAM and other attempts to measure an alienation syndrone, and its indirect derivation from alienation theory would suggest that it is a valfd and useful tool with which to test alieration theory itself.

\section{FACTORS COMMNLY ASSOCIATED WITH ALIENATION}

As noted earlier, several concepts are associated with alienation. Two of these, the concepts of loneliness and social isolation, were defined by Gould (5, p.7) as "... conditions and correlates of alienation, (that)...should not be confused with alienation itself." Thus, Could saw these concepts as parts of the process of alienation as opposed to the state of alienation as reflected in the feelings and attitudes of the individual. This rriter vieved crime and deinquency as being, also, possible correlates of alienation, but not alienation itselif, although they are often asscciated with $\dot{i}$. Two other factors often assocjated with alienation, those of anonie and mental illness, deserve more extencive discussion.

\section{Anomie}

Thexe appears to be sone similarity in the theoretical foundations of anonie and alienation. Davol and Reinanis (25, p.215) pointed out 
that Durkhein (who introduced the rem "anomie" into sociology) inderstood anomie to be a condition of sociesy characterized by normiessness, rulessness, and a failure of́ society to "curb man's inborn impulses." Durkheion (27, pp.243-246) learned that sudien increases ox decreases of national wealth were accompanied by wat he called "anomic suicide." Since fluctuations in wealth were correlated with rates of suicide, it might be inferred that the fact of poverty is not the cause of suicide but rather that the uncertainty and doubt produced by rapid change are usual factors. Aiken et. al. (25, p.94) found support for such a suspicion when they discovered that Packard workers who experienced change of incone, upward or downard, expessed more feeitngs of anomie than those who were able to keep their incouss in Iine with what rhey earned bejore the tackward compan lay ott. The similarities between these considerations and Keniston's theory of the alienating effects of rapid technological change cannot be overlooked.

The disjuncture between the psychology of the individual and the conditions of society, as expressed in theorles of alienation, is also etphasized in the theory of anomie used by Herton. According to Davol and Reinanis (26, p.217) Merton distingushed between psycholcgical anomie and sociological anomie. For Mertin, anomie was the conilict between socially prescribed aspilations and socially ronditioned mears to the achievement of those aepirations. He seperated anomie as a state of society fron the possible outcomes in the psychology of the individial. In this writer's view, a failure of the individual to project personal espirations that are congruant with the social

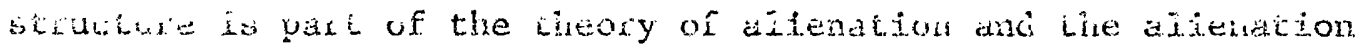


process. Thus, anomie as a psycholcgical state should appear very sinilar to alienation taken to be a set of feelirgs and attitudes. These considerations suggest that concepts of anomie and alienation overlap. Various observations and findings support this suggestion. For example Dean $(20, p .758)$ found a correliation between his scale of normlessness and 5role's scale of anonie of .31, Also, Davol and Reinanis (25, p.221) noted that Nettien found a correlation of plus .309 between his scale of alienation and the Srole scale of anomie.

Gould (5, p.4) ventures the assertion that two of Merton's listed modes of adaptation to anomie are related to alienation. Merton's "modes of adaptation" to the anomie state of society, as Jisted by clinard (27, p.I6) were: conformity, innovarion, ritualisu, retreatm isni, and rebefition. Gould $(j, 0.4)$ related ritialism and retreatista to alienation. He reserved the tarm anomie to rerer to causative social conditions and the term alienation to refer to psychological outeomes. Govld's reservation of the term "aljenation" to refer to psychological outcones of anonic social conditions poses the question of whether or not his "feelings of alienation" play a part in all five of Merton's "nodes of adapcation." It also raised the question of whether the correlated set of feelings used by Gould co construct the MH, through subsequent research, will be enlarged to give evidence of a wider syadrome that can be related to a wider yariety of modes of adatation. 
Mental Iiness

References to discussions of alienation in terms of se1festrangement, doubts, distrust, feelings of inadequacy, and hesitancy in making comitments inevitably presented the protidem of whethei alienation was not some form of wental illness and whether it did not give rise to mental illness. Uniortunately, research into alienation has not made clear the relationsips between alieration and particular adaptations or life styles. Perhaps these many questions prompted Propper and Clark (28, p.314) to call for research that would reveal whether alienation was a nornative trend, a transicory pheromenon, or a deviant psychological aspect of development. Current theory seems to indicate that alienation can be any one or ali three of the above. Nertoti understood alienation ds a generaitzed response to social anó cultural change. He believed that alienation can be accompanied by many behaviors that are seen as deviant but are nomal responses to pathological social conditions. Gould (5, p.12) agreed with Merton and he stated that the relationship between various forms of mental illness and alienation are "... not entirely clear." This position was also that of the writer for the purposes of this study.

Parf of the difficulty in relating alienation to mental ijlness may sten from the difficulty of extracting from personality theory a sutiable definition of maladjustment based on individual characteristics. The fact that Stxuenirg $(23, p .769)$ found alienated individuals in many different tyges of populations suggested that alienation in at least tems of fimctional abilities should not be considered the same as mentai ilness, A different perspective cuntins a theory of 
neurosis as suggested by Karen Horney is applied. Horney (29, pp.26, 103) saw neurosis in terms of rigid defenses against anxiety that are Eurctional or nonfunctional depending upon the cultural or subcultural context within which the individual lives. Therefore, alienation, if it were a form of neurosis, could be found in diverse populations. The diversity of life situations of the alienated, in the context of Horney's theory, does not subtract from the possibility that it is a stage or form of mental illness.

However, Davids found some evidence that the alienated tend to be maladjusted in a clinical sense. Davids (21, p,26) found that the highly alienated see themselves as being less than their own ideal person more often than did the non-alienated. Evaluation of subjects by a clinical stati revealed that the alienated, more often than others, evidenced weak ego structures. In another study, Davids (22, p.54) found that the perceptions of the highly ailienated and those low on alienation varied from reality about the sarse amount. The highly alienated deviated in the direction of alienation items whereas those low on alienation deviated in the direction of low alienation items. Davids' syndrome of alienation, consisted of egocentricity, distrust, pessimism, anxiety, and resentment, and his findings were related by Ansbacher ( $3 I$, p.212) to Adlex's concept of "lack of social interest," a factor underlying most nental illnesses.

The observations of Ansbacher and Davids, then, lend some evidence that alienation may be associated witis mental illness. To assume that mental iljness is equajly associated with alienation would be an error. A weak eto struckure may not resuit in mentai iliness. 
The fact that the alienated have a relatively accurate, although different, view of reality, suggests that they might be able to adapt: their ego functioning to the conditions of life in a number of ways. The possibility that alienation is some state of tension that can be resolved by the adoption of a number of ways of functioning, mentai illness being one such way, remains open. It would appear nore useful, then, to interpret the findings of this study in terms of ways of functioning to which the aljenated subjects may appear more prone than subjects with low alienation.

\section{THEORY AND DISCUSSION}

The theorists such as Marx, Fromm, Keniston, Lynd, and Henry appear to be saying that whenever society does not offer sufficient opportunity for the individual to develop a sense of self that is congruent with socially derined roles, alienation will result, other authors, who founded their research on such theories, learned that alienation, as it exists in the individual, is a syndrone of feelings and attitudes commonly associated with tension and discomfort.

Frikson (12, p.211) stated that self-identity comes about as a result of the iniegration of previousiy confuced selves into a coherent set of roles, or selves, that secure social recoguition. Exikson's views of the process by which selif-identity is achieved seemed to be the reverse of the prosess that, in theory, produces states of alienation. Whis witer feals that the writers tentioned above have analyzed that part of the process of sejf-jdentity formation neglected by Erickson, that is the part played by social forces that condition the 
availability of roles, and that, therefore, influence the formation of self-icientity.

Consequently, this writer believes that alienation, as a syndrone of feelings and attitudes is symptomatic of inadeciately ceveloped selfidentity. The failure of an individual to achieve a coherent self that is congrient with recognized social functions, or roles, results in feelings and attitudes of altenation. These feelings and atituces are viewed by the writer as indicators of a state of tension within the alienated individual. The process of alienation, then, consists in the individual's efforts to achieve self-identity within the sodial structure, his experience of difficulties in achieving seIf-identity, his experience of the tension involved in living with deficient selfidentity: and his efforts to resolye the semsion of alienation through adaptive or maladaptive behaviors.

As tension, alienation cati conceivaly give rise to many adaptive or maladaptive forms of behavior. Some individuals way be abie to reduce the tension to tolerable jevels by achieving partial selfidentity through a portion of their availabie social roles, Reniston's (4, F.341) concept of "little alienations" (feelings of alienation associated with and linited aspect of 1ife) would suggest the possibility that partial self-identity could solve the problen of tension. On the other hand, Gold $(36, p .134)$ speculated that some delinquency eau be explained as negative self-idertity that replaces a sense of the seIf as fajlue with a self that draws more social recognition. In Fact Cold used the serm "regative identity" in Erikson's (12, p.172) meaning, that is, contempt for soctajly deftred, "proper" roles and 
identification with roles in conflict with social expectations. Gold believed that negative identities may resolve the tension growing from a sense of powerlessness. Davids' studies, cited earlier, suggested that the tension of alienation might lead in the direction of mental. illress. In support of this contention, it should be noted that Erikson (12, p.88) believed that some individuals may elect to becone nothing rather than continue the struggle for identity, a choice that, in Erikson's view, leads to mental illness. Converse1y, Nathan Slder (37, p.331) described the "rage for order" evident in the behavior of the alienated who do not give in to inertia and apathy. The "rage for order" is hyperactivity designed to explore the self and the social. enviroument to establish reference points that can serve to define the

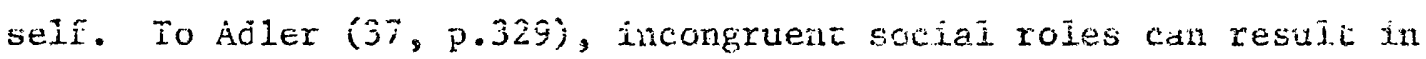
the antinomian personality, a personality that attempis to discover, entirely within the self, some congruency that may reduce the critical need for identity. Thus, Adler seemed to feel that alienation can result in extreme individuality. Davids suggested that it can be a cause of mental illness. Gold felt that alienation car be resolved through criminal behaviors. This writer, who views alienation simply as a state of tencion, feels that all three of the above resolutions of alienation are possible. He would add the possibility that alienation tension can oa resolved by the formition of healthy, positive, although perhaps partial, identity. Empirical research nay reveal other forms of adjustment and it may show which forms of adjustient teno to predominate ancrge the alienated. 
The writer has derived the theoretical. concepts presented in this section from his understanding of the literatire reviewed in the chapter. The theory is presented again, in greater detail, in the concluding chapter where it serves as a means by which the findings of the study can be understood. Chapters II and IV present the nethodology of the study and the findings. 
CHAPTER II

METHODOLOGY

Alienation, for the purposes of this study, was viewed as a state of tension that can give rise to many modes of adaptation. The theory described in the last chapter presented the alienation process as consisting of three parts, the state of alienation tension in the individual, the conditioning soctal forces, and the actions and reactions between the alienated individual and his environment. The theory also presented a position which stated that alienation occurred when society did not allow sufficient availabijity of opportunities for the individuai to integrate a coherent self into the social structure.

It seemed to this writer thet the studies that examined the behavior of alienated adolescencs would be particularly valuable in understanding the process of alienation, considering the importance of identity formation in that stage of life. In this vein, Erikson $(12, p .156)$ stated that the adolescent years are of crucial importance in the fometion of identity. It is during these crucial years shat the adolescent must achieve the following three tasks as outlined by Erikson: (1) to maintain ego defenses against growing impulses, (2) to consolidate past achieverents in line with work opportunities, (3) and to resynthesize childhood indentifications in concordance with roles offered by some wider section of society. Therefore, the adolescent, to achieve identity, must cone to terms with those soctal forces that, 
In an industrial society, according to Marx, Eromi and Keniston, are apt to produce alienation.

Josselyn (38, p.27) agxeed that adolescents are subject to alienating forces. She stated:

His [the adolescents] behavior is unpredictable because it is determined by the confusion within him; he is not protected by enforced compliance to well estabisished rituals and laws. He is told in effect to grow up -.. to achieve an undefined state, he is not told bow to grow up.

It would appear that Josseiyn felt that the adolescent is affected by a social confusion that may be very much like the concept of anonymous authority discussed by From and Keniston. Not able to know what identities will be acceptable over a pericd of time, the adolescent has difficulty shaping his own matural inclinations into an identity comensurate with the roles availabje tir a wider society. If as Erikson believed, a major proportion of identity consolidation and formation occurs during the adolescent years, then the adolescent must tend to be more prone to alienation thin those at other stages of life.

Knowledge of the adolescent's experiences of alienation and his various adaptations to it may prove helpful to edvcators and counselors who seek to help the adolescent in his task of assuning a healthy identity. A specific tash of educators and counselors may be to assist the adolescent to avoid the tension of alienation and to develop an identity with the wider society. This writer believed that alienation creates a state of tension which makes the individual particularly vulnerable to influences from significant others who represent authority and socially recognized roles. Theretore, sensitive educators and 
counselors who understand adolescent alienation, can aid piany individuals to adapt to the tension of alienation in positive, healthy, rather than negative, maladaptive ways.

The task of aiding adolescents to assume identities within the wider society has been assigned, for the most part, in our society, to the bigh school. Since the high school affects persons at a time of Iife most crucial to identity formation, it must be considered an important institution involved in the alienation process. 4 In view of these facts, the aim of this study was to ojtain some descriptions of the behaviors of alienated and non-alienated high school students as those behaviors could be observed within the high school environmert, and to compare the behaviors of the high aifenation subjects and those of low alienation. School personnel were asked to describe the study subjects' behaviors by seiecting descriptive statements from a Faculty Questionnaire. In order to deternine the rejationships between behavior descriptions and degrees of alienation, the subjects were divided into three groups according to their scores on the Multiple Alienation Measure (MAM) devjsed by Gouid (5).

${ }^{4}$ Coleman (39, p.83) stated that "By extending the period of training necessary for a clidd and by enconpasing nearly tire wiole population, irdustrial scciety has made of high school a social systen of acolescents." This statement suggested that the assignnent of adolescents to one institurion can serve to cut them off fxon adut identitiss. Tannentau cited a survey of social scientists, the najority of whow believed that youth's activinies are a special instares of subeulture. Apparentiy, assjgning the task of aiding adolescent developinert to a single type of institution may be, in itself, alienating, because it tends to exect barriers to contact with aduit. identities. 


\section{THE HIGH SCHOOL.}

Originally, it was hoped that a typical, coeducational high school with a student body that was representative of the adolescent population of a community could be enlisted for the purposes of this study. However, delays in negotiations with two such schools made acceptance of Bensor High School's offer of a study population necessary in order to stay within the time limits of the study.

Benson High School is a technical high school in Portland, Oregor. It accepts only male students, and at the time of the study, it had approximately 1950 students. Students are accepted at Benson from all of the high school districts of Portland. Although emphasizing technical training, Benson offers a complete high school program comensurate with that offered by more typical high schools. In addition, it offers an extensive curriculum in technical fields, as well as an effective job placement program for graduates. Students are accepted at Benson on the basis of their applications, which are judged according to their interests, apptitudes and discipline records. Thus, Benson High School must be viewed as an atypical high schooi. 5

\section{SELECTION OF SUBJECIS}

The subjects selected for this study were al 1 Benson seniors. The rriter believed that seniors, since they are faced with decisions affecting their adult lives, could relate to the items of the MAM more

5Fr aditional infornation concerning Benson High School, see Appendix $A$. 
readily than younger adolescents. Moreover, with the exception of recent transfers, seniors have been in contact with the school personiel for greater lengths of time than students in the lower classes. The writer felt that this fact might serve to increase the accuracy of the school personnel's reporting of behavior on the Faculty Questionnaire. It was hoped, then, that the use of seniors as subjects would improve the information gained from both the MAM and the Facilty Questionnaire.

Negotiations with several schools revealed that a rancom sample of seniors would result in selection of students with few teachers in comon. Therefore, in order to obtain behavior descriptions from school personnel who knew of the subjects, the cooperation of a prohibitively large number of personnel would have been needed. To overcome tinis dificiculty, oniy tie students of two social science ciasses were used as subjects. This plan made it possible to Iimit the number of teachers who were to respond to the Faculty Questionnaire to the two who taught these classes.

This plan appeared feasible, largely because all senioxs at Benson take social scjence classes, and because some of these ciasses, in the estimation of theix teachers and the principal, are attended by students who, as a group, represent a fair cross section of the students at Benson. Two such classes were selected for the study by rhe principal. These two social. seience classes contained a total of fortynine students. On the day chat the lifir was administered, five students Were absent, one student rofused to respond to the MAM, and one student failed to conplete the MAM. Consequently, the subjects of this 
study were forty-two male seniors who attend one of the two sociai science classes selected.

\section{SELECTION OF SCHOOI. PERSONNEL}

By information obtained in preliminary interviews with the principal and the teachers, it appeared that these subjects were likely to have had contact with thres other faculty members, other than their sociai science teachers. Each subject was counseled by one of two counseiors, and, if a subject had had problems of conduct, he was likely to have had contact with the vice-principal, whose function is to handle student discipline problens. Therefore, five faculty members were asked to describe the behaviors of the subjects by using the Faculty Questionnaire. These faculty members, in sumary, rere as follows: (1) a male social science teacher who also coached westing, (2) a female social science teacher, (3) a male counselor who also supervised sports, (4) a female counselor, and (5) the vice-principai.

These faculty members appeared to comprise a minimum number necessary to obtain adequate information about the behaviors of the subjects in the terms of the three behavioral categories of the Faculty Questionnaire. The teachers, for example, would have had opportunity to observe the subjects' academic approach, at least within their social anience classes. The counselors were viewed as having, through counseling session, a variety of information about subjects' behaviors. The vice-princtpal was relied upon for observations of subjects' conduct. These five faculty members, then, appeared to have, among 
then, all of the types of information about subjects' behaviors of interest to this study.

IV. ADVANTAGES AID USE OF THE MULTIPLE ALIENATION MEASUEE

The development of the Multiple Alienation Measure has been discussed in the introductory chapter of this study. The MAM measures alienation defined as a ".. general or core syndrone consisting of feelings of pessimism, cynicism, distrust, apathy, and emotional distance" (5, p.19). This definition of alienation vas used in this study, and the MAM was used to divide the subjects into groups according to degree of alienation.

The MAN offexed several advantages to the writer's study. First, Gouid selected icems appearing in several studies involving a wide variety of populations, and his items measure several general dimensions of alienation. Consequently, the MAM was ilkely to be a valid measure of alienation with nost subject samples, such as the adolescent boys who were the subjects of this study. Second, the MAM was a short instrument. The time linjtations of the subjects and their school persomel in this stualy mad use of the MN imparative. The riter considered Nether"s seventeen-item neasure, because of its shortness, but rejected it on the grounds that (1) the ftems were nore appopriate to an oldex popisation and that (2) tive measure addresed irsejf to only che dimenston of aljenation, chat is, "estrangenent from society." The MAM dut zot suffer from these shortconings, and it promsed to be the nost valid and convenient reasire to use with high school serior boys. 
The MAM was adnimistered to the subjects during their social science class periods. The measure was presented as a confidential survey on which they ccuid indicate their feelings about certain aspects of the world we live in. The subjects could respond to each item by selection of one of six possible responees that were arranged in an agree-disagree contenium. The twenty items were presenced without statement opposites or dumin statements, because the writer felt that such statements might reduce the validity of the measure. 6

The completed MAM's were scored by the plan devised by Gould (5, p.28) who assigned values to the responses as follows: strongly agree, 7, agree, 6, not sure but may afree, 5, not sure but may not agree, 3, disagree, 2, and strongly disagree, 1. Gould assigned a value of 4 to those statemente to which tis subjects did not respon. However, no subject in this study fajled to :espond to any statenent. High scores on the MAM indicate high degrees of alienation, and low scores indicate low degrees of alienation. The range of scores of the subjects was divided into three equal parts in order to divide the sample into groups of differing degrees of alienation. Those whose scores were in the upper third of the range were designated as high alienation subjects (HA ${ }^{\mathrm{S}} \mathrm{s}$ ), those whose scones were in the middle third of the range were designated as moderately alienated subjects (MA's), and those whose scores wexe in the lower third of the range were designated as low alienation subjects (IA's). With tilis nethod of

SThe torm in which the MAM was used is shown in Appendix $\mathrm{B}$. 
grouping, it was possible to examine the relationships between behaviors described by school personnel and the degree of subjects' alienation.

V. DEVELOPMENT AND USE OF THE FACULTY QUESTIONNAIRE

The Faculty Questionnaire was constructed to provide school personnel with a uniform way to report theix observations. of subjects" tehaviors. It consisted of twelve statements describing behavior in three categories. Thus, there were four statements in each category. Faculty members were asked to select one statement from each category to describe each subject, of to place a check mark on the response sheet if they did not feel that their acquaintance with a subject was sufficient to permit then to select a statement for that subject in a particular category. ?

Faculty members' observations of subjects' behaviors wexe used in this study, rather than the recorded information for two reasons. Fixst, recorded materials were not available to the writer. Second, some information that was important to the study might not have been found in recorded materia1. The approach used, made necessary the construction of statements that could be selected on the basis of general impressions of subjects ${ }^{\prime}$ behaviors gained fron personal acquaintance with subjects and from very easily remembered incidents of subjects" behaviors. Consequentiy, the teim "behavior," as used in this study, was defined as the trends of subjects' behaviors as observed and viewed by school personnel.

7 The Faculty Questionnaire is presented as it was used in the study in Appendix C. 
In constructing categories of behavior that could be related to behaviors within a school, and, therefore, be easily understood by faculty nembers, the writer found Colenan's (39, F.83) study of student goals within the adolescenc subculture to be useful. Coleman divided the high school student body's goals into four types: "brilliant student," "the leader in activities," "most popular," and "athletic star." These goals suggest a comprehensive way of looking at behavion in a high school, but they had to be considerably modified in oraer to be translated into behavioral terris. For example, "athletic star" and "leadership in activities" suggested to this writer the behavioral category of "engagement in activities." "Briliiant ștudent" suggested the behavioral category of "academic apprcach." "Most popular" seemed to be a description that would invoive fnformal relationships that could not be accurately reported by school persomei. Therefore, no behavior category was projected to correspond to "most popular." Coleman omitted the goals assumed by those who Eehave in negative ways within the school. However, this consideration was important to a study of alienation and behavior. Consequently, a third category, that of conduct, was created for the purposes of the study. The three

categories of behayior exanined by the Faculty Questionnaire are, then, Engagement in Activities, Academic Approach, and Conduct.

\section{Conduct}

The four statements constructed to describe subjects' conduct were designed to allow faculty nemers to reflect the degree of seriousness of a subjects misconduct in terms of the school's dixipinary 
reactions to that miscondict. The first statement described a well behaved subject, or one who had "no behavior problens." The second statement described a subject whose discipline problems are handled in the classroom, that is, a subject with "mild behavjor problems." The third statement describec a subject who was sent to the office and may have been suspended once, or a subjert with "definite behavior problems." The fourth statement described a subject who was suspended more than once, or a subject with "extreme behavior problems."

Although all five of the faculty nembers felt that the items of: this category were self explanatory, the teachers and counselors were unsure of many of their responses. Therefore, only the descriptions selected by the vice-principal. were used. The writer believed the exclusive use of the vice-principal's responses was reasonable because he handles all discipline problens that are sent to the office, and he keeps himself informed of other problems of misconduct.

A number of authors have associated ailenation with behaviors which bring the individual into conflict with authority. ${ }^{8}$ Dorn's (41, p.534) study s $_{3}$ particilar, must be taken seriously, because he offered enpirical evidence that aljenation is asspciated with delinquency. Dorn studied the degree of alienation of institutionalized delinquents, of non-institutionalized deiinquents, and of nondelinquents. He found that the non institutionalized delinquent group was definitely more alienated than the other two groups. The institutionalized delinquents were more alienated than the non-delinquents.

EFor exanples see Bernstein (42), Dorn (41), Gold (36), Adler (37), and Keniston (4). 
Dorn's findings suggested that the common association between alienation and norm-violating behaviors may be nore than an intuitional assumption. In line with Dorn's findings, it was expected that highly alienated subjects in this study would display more sericus discipline problems than those of lower alienation.

\section{Engagement in Activities}

The four statements constructed to describe activities were designed to draw from faculty menbers an estimate of the degree of subjects' involvement in activities and, a1so, some indication of whether a subject engaged prinarily in sports or other extra-curricular activities. The fact that only one subject was described as active in sports only made the goal of dividing subjects according to their preference for sports or other extra-curricuiar activities impossible to achieve. However, responses to the statements did reflect the degree to which subjects were observed to engage in activities.

The statements, as constructed and used, then, designated three. degrees of involvement. The first statement described a subject who was not involved in activities, or an "inactive" subject. The second and third statements, which were considered together, described subjects who engaged exclusively in sports or other extra-curricular activitjes, or the "moderately active" subjects. The fourth statement described subjects who ergaged in both sports and other extra-curricular activities, that is, the "very active subjects."

The vice-principal did not describe subjects in this category, and the teachers described only a few subjects' activities. Therefore, 
only the descriptions of subjects engagement in activities selected by the counselors were of use in the study. Consequently, the study relied on the counselors" very general. knowiedge of subjects' activities which they have gained in rather indirect, rather than direct ways.

Several studies suggested some expectancies concerning the alienated individual's ergagement in activities. For eranple, Bell (43, pp.109-110) found that subjects with high anowie tended to participate in informal and formal groups less frequently than did those who were low on anomie. Keniston (17, p.331) found that his extremely alienated college students tended to prefer the spectator role in their extracurricular activities. Gould $(4 t$, p.48) fovrd his alienated subjects to be more conforming in small groups, but they did not engage other group memhers as frequenty an did those with low alienation. These studies suggested that the alienated might engage in activities less frequently than those of lower alienation, and that when they do engage in activities, they do so in a passive role.

\section{Academic Approach}

The four statements constructed for the category of Academic Approach were designed to elicit from faculty members some indication of the degree to which the subjects attempt to do well acadamically, and the degree to which the subjects prefer to work individualiy or with groups. However, the teachers, whose descriptions were ust, interpreted the phrase "individual assignnents and projects" to mean, not only worli done individually, but work done for extra credit. The 
phrase "class discussion and group projects," then, was interpreted by them to mean the regular work assigned to the whole class. 9

In spite of the risinterpretation of the statements, the goal of eliciting indications of subjects' motivation to do we11 academically was accomplished. One statement, in the termis understood by the teachers, descrjbed a subject: who does not do well at regular or extra work, or a "poor student." Another statement described a subject who does well in regular work only, or a "good student." A third statenent described a subject who does well in regularly assigned work and who also does extra work, that is a "very good student." The remaining statement described a subject who does extra work but does not do well in regularly assigned work. As would seer logical, this statement did not describe any subject, and, thorefore, was not ued by cither teacher. Thus, the teachers used three of the statements to describe the degree to which the subjects engage the educattonal process of their social science classes.

The teachers' descriptions of subjects' academic approach vere the only ones used in the study for two reasons. First, the vice-principal did not describe subjects' academic apprcach. Second, the counselors described the academic approach of subjects by inference from their experiences with them in incerviens and not from observation of subjects' stidy or classrocil benavior. It seemed reasonable to use only the teachers' descriptions, even though they described behavior in onjy one class, because they were able to select descriptions on ${ }^{9}$ See tha statements under Academic Approach, Appendix C. 
the hasis of direct observation. Also, it should be noted that each subject was described by only one teacher, since each teacher described only those subjects who attended his class.

The literature reviewed for this study has offered little information from which expectations of the acadenic performance of the alienated could be drawn. Struening found alienated individuals among many groups of various academic levels, and Keniston and Gould found highly alienated individuals in college populations. The range of samples studied by these authors would suggest that the acadenic abilities of the alienated wiay vary widely. Yet, the possibilities that the alienated tend to isolate themselves from others in their academic efforts, or that they might perform poorly because of resistance to the authority of the teacher have $1 \mathrm{ed}$ the writer to expect the alienated, in high school populations, to be less academically able, as a group, than those with less alienation.

\section{SUMAARY OF STUDY METHOD}

The forty-two subjects of the study were male, senior students at Benson Polytechnic High School wiso attended two required social science classes. The faculty vembers who described their behaviors were their two sccial science teachers, two counselors, and the viceprincipal.

The aim of the study was to examine the relationships between the subjects' degree of alienation and theix behaviors in three areas of school life as described by school personne1. The subjects' scores on the Nuliple Alienation Measure were used to determine their degree 
of alienation. The subjects, for purposes of comparison, were divided into three groups whose nembers were those whose scores were in a comon third (nighest, middle, or lowest) of the sample's range of scores on the MAM. Each subject was described by one teacher in terms of whether (1) he neglected his studies, (2) completed required studies, or (3) did required work and also extra work. Each subject was described by one counselor in terms of whether he (1) does not participate in activities, (2) participates in either sports or other extra-curricular activities, or (3) participates in both sports and other extra-curricular activities. Additionally, each subject was described by the viceprincipal in terms of whether (1) he did not have discipline probiems, (2) had problems oniy in class, (3) had froblems that resulted in being sent to the office and possibly one suspensions or (4) hat prohlens resulting in more than one suspension. The described behaviors of the alienation groups were compared in the nanner presented in the folloring chapcex to determine the existence, if any, of reiationships between these behaviors and the degree of alienation of a subject. 
CHAPTER III

\section{FINDINGS}

The use of the Faculty Questionraire to describe degrees of engagement in activity, of academic effort, and of the seriousness of misconduct made possible the deternination of the significance of behavioral differences among alienation groups by use of chi-square tests. Each descriptive statement was assigned a word or phrase which reflected a degree or observed behavior. Specificaliy, the words and phrases were, for Engagement in Activities: "inactive," "moderately active," and "very active;" for Academic Approach: "poor student," "good student," and "very good student;" for Conduct: "no behavior problem," "mild behavior problem," "definite behavior problem," and "extreme behavior problem."

The benaviors of the alienation groups were compared in terms of the three categories in Tables I, II, and IV. Also, the subgroups comprised of those subjects described as inactive in each alienation group were compared in Tables III and $\mathrm{V}$ with respect to Acakemic Approach and conduct. The definition of two otiner sets of subgroups, that is, involved students and the well behaved, was possible, but only the subgroups described as inactive offered observable differences in behavior in the two remajning categories. Therefore, the "Inactive" subgroup was the only one examined. 
The Ifudings of the study were discussed in four sections beginning with a presentation of the distribution of MAll scores, followed by sections concerning behaviors in the order of the categories on the Faculty Questionnaire. The inactive subgroups were compared in the sections dealing with Acadenic Approach and Conduct, that is, the two remaining categories of behavior.

\section{DISTRIBUTION OF MAM SCORES}

The distribution of MAY scores (see Figure 1) was very nearly a normal one. The possible range of scores was from 20 to 140 points. The range of the study's distribution was from 53 to 107 points. The mean score was 77.5 , and the nedian score was 76.5 . Thus, the distribution showed a slight positive skew, The subjects were divided into three alienation groups as follows: 9 subjects whose scores were in the upper third of the range, 1.6 subjects whose scores were in the middle third of the range, and 17 subjects whose scores were in the Iower third of the range.

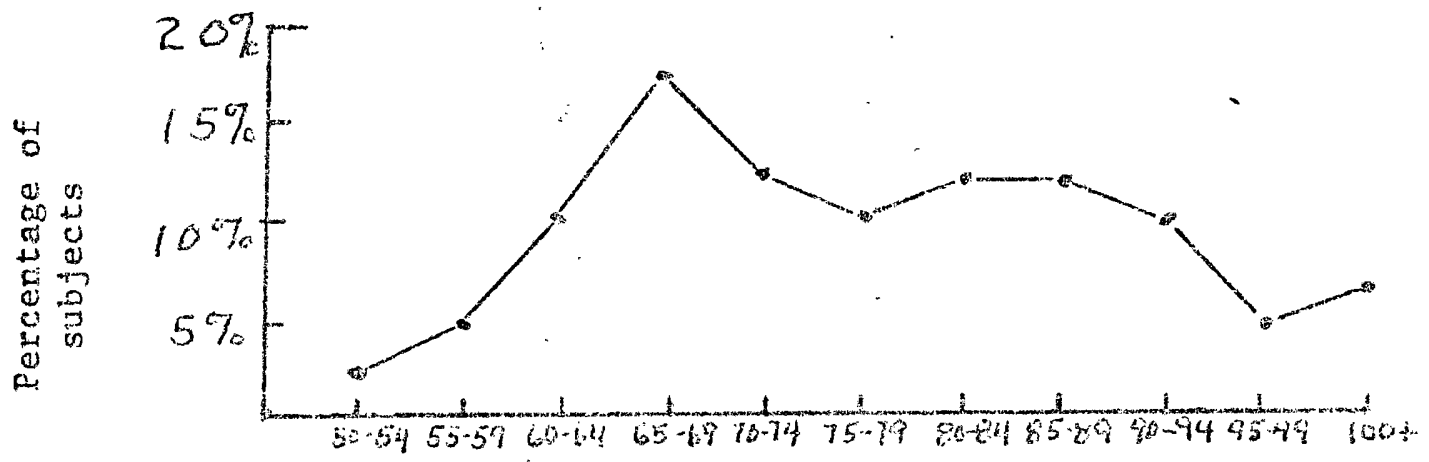

Figure 1. Distribution of MAM scores of the 42 subjects. 
The positive skew of the distribution was slight compared to the positive skew obtained by Gould (5, p.37) from a distribution of the MAM scores of 429 male, university psychology students. 10 The difference between Gould's distribution and the present one was significant at the .05 level. The value of $z$ necessary to demonstrate significance was 1.64 , whereas, the value of $Z$ obtained by a one-tailtest was 6.07. Although othex factors might account for this difference, the writer believed that it demcnstrated that fewer alienated high school males, like those at Benson, go on to college.

\section{IT. ENGAGEMENT IN ACTIVITTES}

The study revealed no significant relationship between alienation and the counselors" descriptjons of subjects" involvement in activities. A chi-square test for the .05 level of significance was applied to the figures presented in Table I. A chi-square value of 9.488 was needed to demonstrate significance, but the test value of the table was only 4.279. Wuch below that needed for significance.

However, it should be noted that the riajority of subjects in all. three alienation groups were described as being inactive. This stiggested the possibility that the reasons for attending Benson, (to obtain vocational and technical training in an a11 male school) may reduce the inportance of activities for the majority of Benson students.

Aithough there was no statistically significant difference among the alienation groups in counselors' perceptions of their involvement in

$10_{\text {could's }}(5, p .37)$ distribution showed a mean score of 63.8 and a median score of 61 , witn a standard deviation of 14.3 . 
TABLE I

\section{ALIENATION AND ENGAGEMENT IN ACTIVTTIES \\ AS DESCRTBID BY COUNSELORS}

Degree of Observed Eehavior Alienation Group, Numbers of Subjects, and
Per-cent of Alienation Group

High

Alienation
Low

Alienation number per cent number per cent number per cent

Inactive

6

(67)

11

(69)

9

(53)

Moderately

Active

1

3

(19)

7

Very Active

Totals

2

9
(22)
2 .

2.

$16 \cdot(100)$

17

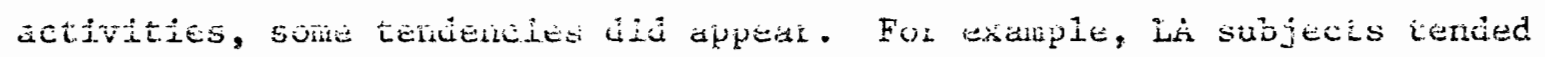
to be described as moderately active more often than the subjects of the other two alienation groups. They were aiso inclined to be described as inactive less often than the subjects of the other two groups. IA subjects, then, tended to be seen as more active in terms of moderate activity. II This tendency, although very. slight, conforms to the expectation that alienation is related to aroidance of activity engagement in extra-curricular activities.

The per centage figures showed a greater inclination of HA subjects to be described as inactive or very active, and a lesser tendency to be described as moderately active. In other words, the alienated were prone to be described by the extreme statements. However,

${ }^{11}$ As explained previously, IA refers to low alieration, MA to moderste alienation, and bi to high alienation. 
a change in description of only one of the two HA subjects described as vary active would eliminate the apparent tendency of the group to fall into extremes. This tenoncy was mentioned only becalse it seemed to correspond to a sinilar tendency in the teachers' descriptions of the Academic Approach of the alienated.

\section{ACADEMIC APPROACH}

Again, as with Engagement in Activities, there appears to be no significant relationship between alienation and descriptions of the degree of subjects' involvement in social science studies. A chisquare test for the .05 level. of significance was applied to the figures for Academic Approach shown in Table IT. A total chi-square

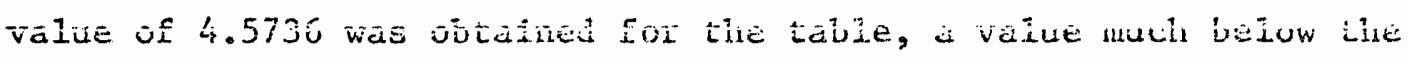
value of 9.488 needed to demonstrate a significant relationship. However, the figure in Table II indicated a inclination for HA subjects to be described as either very good studenta or as poor students. Whereas no HA subject was described as a good student; $31 \%$ of the MA group and $29 \%$ of the LA group were described as good students. This tendency for H subjects to be described in extremes as students appeared to correspond with a similar tendency for HA's to be described in extreme of Engagement in Activities, as was mentioned in the previous section.

Also, among the subjects of this sample, those of low alienation. were less likely to be described as poor students than vere efther the MA's or HA's. The MA group appeared similar to the HA group, except that MA's were not describcd in extromes. The figures for the TA group 
TABIE II

ACADEMIC APPROACH IN SOCIAI SCIENCES

CLASS AS DESCRIBED BY TEACHERS

Degree of Observed Behavior

Alienation Group, Numbers of Subjects, and Per-cent of Alienation Group

High

Ajienation

number per cent
Moderate

Alienation
Low

Alienation

number per cent, number per cent

$\begin{array}{lcccccc}\text { Poor Student } & 3 & (33) & 5 & (31) & 3 & \text { (18) } \\ \text { Good Student } & 0 & (0) & 5 & (31) & 5 & (29) \\ \begin{array}{l}\text { Very Good } \\ \text { Student }\end{array} & 6 & (67) & 6 & (38) & 9 & (53) \\ & -(100) & 16 & (100) & 17 & (100) \\ \text { Totais } & 9 & (00) & -17 & \end{array}$

inaicated a sijght ljkelihood for these subjects to be seen as more involved students than the subjects of the other two groups. Thus, only the IA group tended to confirn the expectation that high alienation would be associated with poor academic performance.

The tendency of teachers to perceive the alienated in extremes continued to be apparent when the Academic Approach of only those subjects who were described, by counselors as inactive was considered, as in Table III. Considering per centage figures only, it was found that inactive $\mathrm{HA}$ subjects were described in extrenes in the sane way that all HA subjects were described. Elimination of the active subjects, however, revealed changes in the percentages of MA and LA subjects as described by the various statements. For instance, jnactive IA subjects were more fxequently described as "good students and less frequently as "poor scudents," or "very good students" thep were aii LA subjects. 
TABLE III
A.CAIDEMIC APPROACH
OF UNINVOLVED
SUBJECTS

Degree of Observed Behavior

Alienation Group, Numbers of Subjects, and Per-cent of Alienation Group

High

Alienation

number per cent
Moderate

Alienation

number per cent number per cent

$\begin{array}{lcccccc}\text { Poor Student } & 2 & (33) & 5 & (45) & 1 & \text { (11) } \\ \text { Good Student } & 0 & (0) & 3 & (27.5) & 4 & (44.5) \\ \begin{array}{l}\text { Very Good } \\ \text { Student }\end{array} & 4 & (67) & 3 & (27.5) & 4 & (44.5) \\ & -100 & 11 & (100) & 9 & (100)\end{array}$

Also, inactive MA subjects were more frequently described as poor students and less frequentiy as good or very good students than were al1 MA subjects. Apparently, there was less of a tendency for inactivity to be associated with involvement in the educational process for HA subjects than for both MA and LA subjects. The MA subjects showed the more intense tendency to be described as poor students when also described as not involved in activities. Inactivity appeareci to be associated, then, with a greater inclination to be clescribed as poor students for the MA group and with a greater tendency to be described as good students (rather than very good or poor students) for the LA group, whereas descriptions for the HA group did not change. 
IV. CONDUCT

The vice-principal's descriptions of the disciplinary reactions of the school to subjects' misconduct is presented in Tabie IV. A significant positive relationship between poor conduct and alienation in this sample was apparent in these figures. A chi-square test for significance at the .05 level was applied. The chi-square value needed to establish significance was 12.592, and the total value of the table was 18.0099 , well over that needed to demonstrate a significant positive relationship between high alienation and serious

\section{TABLE IV}

CONDUCT AS DESCRIBED BY THE VICE-TRINCIPAL

Degree or Observed Behavior

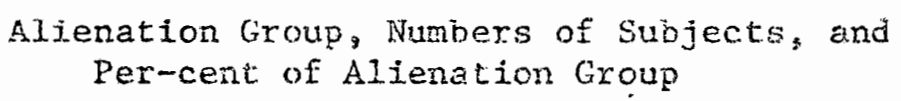

High

Alienation

number per.cen

\section{Moderãe}

Alienation

number per cent
Low

Alienatiori

number per cent

No behavior

Problem

2

(22)

0

(0)

1.

(.6)

Mild Behavior:

Problem

0

( 0$)$

2

(13)

0

$(0)$

Definite

Behavior

Problen

2

(22)

y

$(4.3 .5)$

0

( 0$)$

Extrene

Behavior

Problen

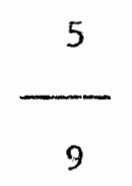

(56)

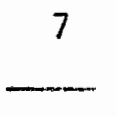

$(43.5)$

16

Totels

(100)

16

(100)

17

(100)

$\mathrm{x}^{2}=18.009$

$F<.05$ 
discipline problems among the subjects of this sample. This finding was in the direction expected if credibility is given to theories which state that norm violating behavior is frequently part of the alienation process.

The significance of this finding, was preserved when gnily subjects described as inactive were considered. However, some changes were noted. For instance, inactive $\mathrm{HA}^{\prime} \mathrm{s}$ and $\mathrm{LA}^{\prime} \mathrm{s}$ were very slightly less well behaved than were all HA's and IA's. On the other hand, MA's showed a greater tendency to be less well befaved than all MA subjects.

TABLE V

CONDUCT OF INACTIVE SUBJECSS

Degree of obseryed Behavior
Alienation Group, Numbers of Subjects, and Peracont of Alienation Grow

$\begin{array}{lll}\text { High } & \text { Moderate } & \text { Low } \\ \text { Alienation } & \text { Alieration } & \text { Alienation }\end{array}$

number percent number per cent number per cent

No Behavior

Problem

1

(17)

0

( 0$)$

1

Mild Behavior

Problem

0

(0)

2

(18)

0

Definite

Behavior.

Problem

2

(33)

6

(5.5)

$(0)$

Fxtreme

Beliavior.

Problem

3

(50)

3

(27)

8

Totals

6

(100)

11

(100)

9

(100)

$x^{2}=12.652$

$\mathrm{P}<.05$ 
Among all MA's, 43.5\% were described as well behaved, whereas among inactive MA's, only $27 \%$ were described as we 11 behaved. Inactivity, therefore, was associated to some extent with greater discipline problems for all groups, but especially for the MA group.

\section{SAMPLE LIMTTATIONS}

The sample of this study is a select one in a number of ways. First, the subjects were al1 boys. Second, they were all students who had been motivated to apply to attend Benson. Third, they vere those who were accepted at Eenson. The third consideration was important because Benson, by its entry requirements, screens out nary students with histories of severe discipline problems. Consequentiy, generaizaticn of the fintings to more heterogenevus pupulations cannot be made with confidence. Similar studies should be conducted with random samples of adolescent populations in order to check the reliability of the tendencies and significant findings of the study.

\section{SUMMARY OF FINDINGS}

A positive relationship between the degree of alienation and the seriousness of disciflinary problems was the only significant relationship found. No significant relationships vere found between the degree of alienation and the degree of involvement in activities, or in the degree of involvenent in social science stidies. However, the figures for the LA group, as compared to the figures for the other two groups, tended, very slightly, to confirm the expectatlons that alienation was 
positively related to avoidance of activities and poor approaches to academic studies.

Some additional tendencies were apparent in the data. First, the alienated tended to be described by the extreme statements in terms of. Engagement in Activities and Academic Approach. Second, the inactive HA subjects tended to be described the sane as all HA subjects, whereas inactivity appeared to be associated with poorer approaches to social science studies for the other two alienatfon groups. Third, inactivity appeared to be slightly associated with poorer conduct for all alienation groups, but especially for the MA group.

It was found that the subjects of this study were significanty more alienated than the sample of college students tested by Gould. Mliat finding suggested to hive writer that high ailenation may be associated with failure to attend college, although many other factors could have been involved. 
CHAPTER. IV

CONCLUSIONS AND THEORY

In the introduction to this study, sone theoretical concepts concerning the process of alienation were presented. The authors who dedt with social forces seemed to be saying that alienation grows fron social forces that tend to hinder the individual in achieving a sense of self that is recognized by and integrated with the sociaj. structure within which he develops and lives. Identity was defined as that state in which the individual had incegrated his various selves with one another and with his social world, either wholely or partially. The writer presented the theory that alienation is a state of cension that makes evident one's lack of identity by expressions of certain feelings and attitudes such as those measured by the MAM. An individual attempts to reduce the tension of alienation through adaftive measures that nay be reflected in the behaviors with which he meets his social situation. Some of the adaptive measures that were suggested vere: the devejopment of negative juentity through norm violating behaviors, the development of individual identity through extreme individuality, the escape from social probjens of identity into mental ijlness, or the behaviors that serve to establish healthy, positive identity. Thus, the writer felt that behaviors designed to reduce alienation tension, if successful, nove the indyidual in the direction of the integration of selves into a socfa1ly renognized identity, whether that identity is socia1ly approved or jisapproved. 
The following paragraphs presents the writer's theory of the ailenation process with an elaboration of the possible types of adaptations that may result from alienation tension. Subsequent sections relate the findins of this study to the theory presented.

Nathan Adler (37) presented a theory of what he cailed the antinomian personality. Like Keniston, Ailer saw the origins of the antironian personality in the rapid changes taking place in society. He felt that changes confuse the individual in his effort to assune roles. Adler $(37, \mathrm{p} .329)$ stated that:

When roles lose their congruance, when the world's responses are no longer reliable and contradict the individual's expectations, specific behaviors energe as an atteipt to naintain an optimal degree of arousal. or activation.

He (37, p.330) went on to state that an individual needs responses from the world that tend to validate the self, and he mintained that the present world is too unstable to provide such validation. Apparenty, Adler, again like Teniston, found the conditions of society to be such that the establishment of identicy is difficult. The antinomian personality attempte adjustment to his state by seeking stimuli in a "rage for order" designed to engage lost boundary points in self and soclety. Conversely, Adjer felt that the atinoutan persunality might also seek to escapa all stimuli, ar ajustinent that was, in the opinion of tiss whiter, a move into apathy. Adjer (37, p.330) stated tiat the individual, unable to effect self-detemination, responds with the opposices of inercia or hyperactivity.

Adler's theory resembled the theory presented by this writer. In sumary, an unstable worlib offere insuficient fedbeck and recogni- 
tion to the peculiarities of the individual. The individual does not develop an identity that is congruent with his society. He responds to the tension of his lack of idertity with adjustment reactions. At this point Adler $(37, \mathrm{pp} .330,337)$ diverges from this writer's theory because he was concerned with a special case of probjems in identity, the hippie character type, or the antinomian personality. He presented the antinomian in personality as one whose adjustment reactions have failed to establish identity with some existing aspects of society. He presented the outcome of this failure as an adjustment that brings about opposition to external orders through an assertion of internal impulse and desire which establishes an order, an identity based upos some principle generated within the self without reference to its congrucate with the social oruer or parts of the sucial uruer.

This writer felt that Adler's account of the process that projuces the antinomian personality is a description of the process of aienation carried to one of its possible ultimate conclusions. It is possible that the "rage for order" can bring the individual into contact with social elements that may make possible the establishment of a degree of identity that can reduce the tension of ailenation to the extent that the process is arrested short of the antinomian personality. However, of special interest to this study vas Adler's assertion that the antinomian personality seeks adjustment through extremes of behavior, that is, through the extravagart, energetic expenditure of erergy in the exploration of self-in-environment, or through the avoidance of all stimuid through apathy. The impression left by Adjer's description was one of a desperata, jutense attempt to mate sence of 
existence in terms of identity with some order within the society, or, on the other hand, an equal1y desperate attempt to achieve peace at the price of isolation from the struggle for identity. This writer believed that the need to reduce alienation tension would lend intensity to the attempts to adjust, and that this intensity, in term, would lead to extreme forms of adjustive behavions.

The extrenes of adaptive behaviors presented iy Adler resembled some concepts related to the process of identity formation as presented by Erik Erikson. Erikson (12, pp.80-81) spoke of an "essential wholeness" in which the parts of an individual and his world, no matter how diverse, have some workable organization. When this wholeness is Iost, the individual, as an energency reaction, may restructure his world so that a part of his organization becones emphasized in a totalistic way. Wholenss impiles an ability to allow all parts to relate, totalism demands that parts outside be left outside, those inside must be left inside. Thus, a part of existence in society must serve as the whole identity. This writer felt that the "rage for order" accompanied by hyperactivity, as conceptualized by Alder, is likely to lead to totalistic solutions to problems of identity because the hyperactivity reflects an intense need to reduce the tersions that: grow from the lack of a socially recognized and engaged, integrated set of selves or identity. An intense embrace of a partial solution to the identity problen, in this writer's theory, can reduce the tensions to the extent that the process stops short of the formation of the antinomian personality. 
Erikson presented another possible adeptation to problems of identity through his theory of negative identities. Erikson (12, Pp. 172-176) stated that, when the social order offers no means to assume positive identities, the individual may strive to be the opposite of what society appears to expect, or to be no one at a11. He described negative identities as "desperate" attempts to regain mastery when positive identities within society are unavalable to the individual through his own means. The identity crisis of adolescence, according to Erikson (12, p.88) often results in the totalistic assumption of the identity of nothingness, rather than in a continued struggle with identity confusion that might result in a positive identity. Adlex's description of the individual who resolves idenity problems by avoidfng all stimuli appeared to the writer to be related to Frikson's assertion that nothingness can be a solution to identity confusion. This writer believes that the "rage for order" can result in what Erikson calls negative identities, either passive or active in nature, or in positive identities of a totalistic partial nature.

Adler and Erikson appeared to start their theories from the same point, that is, from a concept of a tension that grows from difficulties in the establishment of identity. Adler has observed that some fall. into apathy, or, to this writer, a solution through assumption of nothingness as identity. He also remarks on the hyperactivity of other individuals. The writer understood the hyperactivity as a continutng struggie to achieve positive identity that way end in the assumption of a partial, positive ichatity that becomes a totalistic solution, or in a negative identity that asso may be a totalfstic solution. A 
wholistic, fluid identity would probably not be possible as an outcome of hyperactivity within the same social order that created the conditions for identity problems in the first place, unless the essentials of identity formation that were lacking were added.

Alienation was, then, presented as a set of feelings that express the presence of tensions growing from problems in the establishment of identity. The theory of the process of alienation involved social forces that hinder the establishment of identity in the individual, the individual's state of tension, and the individual's attenpts to adjust this tensior. The adjustive reactions, which in turn, affect society, are seen in terms of hyperactivity that may establish partial, totalistic identities, either positive or negative, or a lapse into apathy, triat is, tire assumption of the negative identity of nothingness.

The theory presented above lended itsejf to some interpretations of the behaviors of the Harvard College sophmores who were studied by Keniston (17, p.331). Keniston remarked that these students "... pursue their intellectual interests with such singleminded dedication that they almost completely disregard the convertional distinction between "work' and 'Ecofing off' made by most of their classmates." He observed that these alienated students became "totally ebsorbed" in intel.iectual work that touched a deep or personal "symbolic chord." On the other hand, the alienated students terded to avoid responsibilities, to prefer the role of detached observer in extra-curricular activities, and to be hesitant to connit themselves to pursuits other than those involving only their ow peculiar, personal interests.

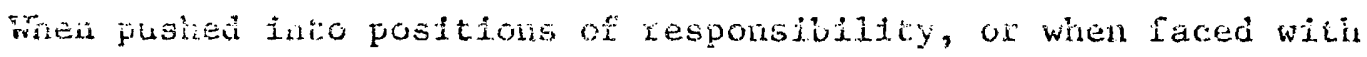


conflict, they tended to escape by leaving on a walk or a leave from school, sonetimes of several years duration.

In the context of the theory presented above, the intellectual role of these students were understood as a totalistic, positive identity, grasped with an intensity, growing from the need to reduce alienation tension, and resulting from hyperactive explorations of boundaries undertaken in earlier school years. The tendency of these students to avoid comitments to other ways of funcioning can be understood, also, in terns of their reliance upon a totalistic identity. A total, partial identity, because it is embraced with intensity, will. narrow the range of social functioning within which the alienated student may be confortable. When society demands that the alienated function in ways not related to his partial identity, he may experience increased alienation tension. It appeared that Keniston's Harvard students who are highly alienated, handled the problem of a narsow identity by maintaining some safety against being pushed into modes of functioning other than those related to the intellectual role. When faced with unavoidable demands to function in ways not related to their partial identity, they tended to handle their increased tensions by simply escaping from the situation.

This witer felt that Keniston's observations of the character.. istics of alichated Haivard students were evidence of the plausioility of the theory of the altenation process presented in this chapter. However, thes theory itself hinged on the assertion that alienation was an outgrowtin of problens in the fomation of identity. Gould and Riein i4j; have completed a piece of research rhat lends some evidence 
to that assertion. They examined the identification of a number of college women with their mothers, and they confirmed a hypothesis that girls with high alienation have identified less with their wothers than have gixls with low alienation. This study, although it considers only a narrow aspect of identity formation, did tend to support the theory that aifenation was a result of problems in the formation of identity. Also, two of Keniston's observations (4, pp.98, 130-134), that the alienated see their fathers as distant and that they evidence problems of sexual identity, would support the possibility that alienation is associated with problems of identity.

The aspects of the theory presented that were important to the findings of this study were the tendencies of the alienated to adjust in Leins of apathy, or in terms of totalistic, partial identity, and the tendency of the alienated to show hyperactive behavior designed to explore the boundaries of possibie identity formation. The findings of this study were interpreted via these theoretical aspects of adjustment to alienation.

\section{CONDUCT}

The findings presented in Tables IV and $V$, that the alienated subjects of the study tended to experience more discipline problems was expected, not only on the basis of theory and general observation as outlined in the introduction, but on the basis of the theory presented in this ciapter. If the tension of alienation leads to hyperactivity designed to engage the selves of the individual in intimate contact

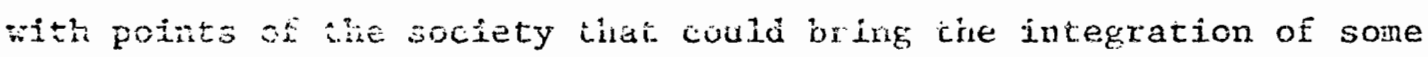


identity, then the relationship of alienation to discipline problems can be understood as evidence of a greater need on the part of the alfenated to find themselves by testing the limits of their school environment.

In the context of this study, the $L \Lambda^{\prime}$ 's appeared to need very little testing behaviors. The MA's appeared to be satisfied with a test of limits that result in one suspenstor, or trip to the office, at most. However, a larger proportion of the HA's seemed to need to test limits to, and beyond the point of being suspended nore than once.

The greater incensity of the testing behavior of the alienated was understood to be a result of a need to reduce alienation tension, a "rage for order" to put it in Adler's terms. The findings of the study, then, seemed to contiru an assertion trat alienation is associated with behaviors that bring the individual into conflict with the values of aithority.

The fincings concerning conduct did not, in themselves, suggest an answer to the question of whether or not conflict with school authority does bring about reduction of alienation tension. However, if in the process of conflict, the subject experiences confirmation of his fdentity as a trouble-naker, he would experience reduction of tension according to the theory presented in this chapter. The fact that HA's use more testing behaviors might indicate that these behaviors do not result in sufficient reduction of alienation tension, or that they do result in tension reducing negative identities that must be maintalned. The figures concerning the academic approach of subjects 
did suggest some ways in which the alienated may succeed in reducing alienation tension within their school experience.

\section{ACADEMIC APPROACH}

Each of the two teachers described their HA students as either very good or poor students, as were shown in Tables II and III. On the other hand, they described the LA and MA subjects as "good," "poor," and "very good." Alienated students then are described by trieir teachers as being intensely involved students or intensely uninvolved students. This finding can be interpreted as a manifestation of the need of the alienated to reuce alienation tension by coptiun of a partial, totalistic jientity as a good student or to reduce alienation cension by going to the other extrere, that is, adontirg a negative ident:ty or an apatiny, with regard to the educational processes of these classes. The HA subjects secmed to avoic the choice of functioning as moderately involved students. To function as a moderateiy involved student may not have affcrded the identity needed to reduce alienation tension. Their behaviors in the classrooms can be seen, then, from the standpoint of two choices. First, about a third of the HA subjects chose to redice alienation tension by avolding the student role in these classes. Second, the other two-thirds appeared to rence alienation teision by enbracing the student role with an intensity that couH result in the astablishment of a totalistic, partial identification as very good social science student. The liA's and LA's who experience less alteraticn tension, appeared to be more comfortable in the role of the moderately involved student. The poor student HA's might have 
acquired negative identity in the classes, or they might have given up the struggle for identity in favor of apatiny. However, the intensity of their embrace of their adjustments was supported by the finding that inactivity did not affect their student identities as it did with the LA and MA subjects.

\section{ENGAGEMENI IN ACTIVITIES}

The findings concerning involvement in activities, presented in Table I, were not easily related to the theory presented in this chapter. A slight tendency for HA subjects to be Inactive or very active vas detected in the descriptions made by the counselors. Yet, this tendency was much too silight to allow an interpretation iri terms of apathy, avoidance, or the expression of special. interest as a totalistic, partial identity.

Perhaps the statements of the category were much too general to allow elaboration upon the diverse forms of behavior that can characterize Engagement in Activities. Classroom behavior and conouct appeared to be less diverse in nature, and vere, for that reason, easier to describe. Aiso, the counselors, in describing activity behaviors, may have iacked the first hand observations and concrete means of inference that were available to the teachers and the vice-principal in terms of acadenic approach and conduct descriptions. The only definitive statcment that can be made concerning the category of involvenent in activities is that the HA's appeared to the comselors to be about as active as were the other subjects. 


\section{SUMMARY}

This chapter presented a thecry of the alienation process with which sone of the findings of the study could be related. The theory presented alienation as a state of tension, measured in terins. of feelings as by the MAM, which grow from difficulties in the estabiishment of a wholistic identity that is congruent with the individual's total society. The alienation tension leads to hyperactivity designed to explors the self and society in search for the possibllities for identicy formation and, thus, the reduction of alienation tension. The hyperactivity may end in the adoption of passive or active rejection of social possibilities for identity, that is, in the adoption of negative identities. On the other hand the hyperactivity may end in the adoption of some positive identity of a totalistic, partial, rather than wholistic nature. Since adjustments to feelings of alienation are designed to reduce tension, they are likely to be intense and extrene.

The texdency of the HA subjects to experience more discipline problems was interpreted as an outcome of intense hyperectivity designed to bring the individual into more intimate contact with the society of the school and the possibilities for the establishment of identity that can reduce alienation tension. The tendency for HA subjects to avold inoderation in theis engegement of the educational process of their social scionces classes was interpeted in terms of their need to reduce azienation tension by adopting regative, apathetic oi positive, totalistic identities. The results of descriptions of encrgenent 
in activities was not interpreted through theory. It appeared that this portion of the study required more specific types of infornation in order to yield meaningful results. 


\section{REFERENCES CITED}

1. Nettler, Gwynn, "A Measure of Alfenation," American SociologicaI Reviek, Vol. 22, Decenter 1957, tp 670-677.

2. Lowrie, Walter, A Short Life of Kierkegsard, Anchor Books, Ioubleday a Co., 1961.

3. Kierkegaard, Soren, Fear and Trembling and the Sicliness Unto Death, Doubleday \& Co., Garden City, New york, 3954.

4. Keniston, Kenreth, The Uncomitsed: Alienated Youth jn Americar: Soriety, De11 Publisking Co., hew York, 1965.

5. Gould, Laurence J., The Ailenation Syadrome: Psycho-Social Correlates and Eenavioral Consequences, Unpubiished Pr.D. issertation, University of Comecticut, Stors, Connecticut, 1966.

6. Marx, Karl; Engeis, Friedrich, "On Alienation," From Images of Han, edited by $c$. Wright Milis, George brazilier inc., New York, 1950.

7. From, Erich, The Sane Society, Favicett Fublications, Inc., Greenwich, Connecticut, 1966.

8. Henry, Jujes, Culture Against Man, Vintage Books, Random House, New York, 1965.

9. Iynd, Helen Merre11, Gr Shame and the Search for Idenitity, A Harvest Book, Harcourt, Brace and World, Inc., Nen York, 1958.

10. Dean, Dwight G., "Alienation and Political Apathy," Sucial Forces, Vol. 38, No. 3, Marsh 1960, pp 185-195.

11. Eappenheim, Fritz, The Altenetion of Moderm Man, Modern Reader Paperbacks, New York and sondon, 1959.

1.2. Rubron, Erik H., Identity: Youth and Gisis, W.W. Norton \& Co., New Tork, 1968 .

13. Toffler, Alvin, Future Shock, National General Co., Bantan Book, Neri pork, Toronto and London, 1971. 
14. Hajda, Jan, "Alienation and Integration of Student Intellectuals," Amexican Sociological Review, Vol. 26, No. 5, October, 1961, pp $758-777$.

15. Brcwning, Charles J.o; Farmer, Malcolm F.; Kirk, David H.; Mitchell, Duncan G., "On the Nieaning of Alienation," Anerican SocioIogical Review, Vol. 26, No. 5, 1961, pp 780-781.

16. Rogers, William R., The Aijenated Student, Board of Education, United Methodist Church, Nashvilie, Tennessee, 1969.

17. Keniston, Kenneth, Young Radicals: Notes on Committed Youth. Harcourt Brace and Worid, Inc., New York, 1968.

18. Byles, John Arthur, Alienation and Social Control: A Study of Adolescents in a Suburban Community, Unpublished Ph.D. dissertation, Washingtor University, St. Louis, Missouri, 1968 .

19. Seeman, Melvin, "On the Meaning of Alienation," American SocioIogica1 Review, Vol. 24, No. 6, Decerber 1959, pp 783-791.V

20. Ilean, Dwight G., "Alienation: Its Meaning and Measurenent," Americar Sociological Revi三. Vol. 26, No. 5, Occober 1961 PQ $753-750$.

21. Davids, Arthony, "Alienation, Social Apperception, and Ego Structure," Journal of Consu?tint Peychology, Vol. 19, No. 1, February 1955, pP 21-27.

22. Davids, Anthony, "Generality and Consistency of kelations between the Alienation Syndrome and Cognitive Processes," The Journal of Abnormal and Social Psychology, Vol. 51, No. 1, July 195.5, pp $61-67$.

23. Struening, Elmer L.; Rjchardson, Arthur H., "A Factor Analytic Exploration of the Alienation, Anomia, and Muthoritarianism Donain," American Sociological Beview, Vol. 30, No. 5, 1965, pP $786-776$.

24. Ajken, Hichae1; Femen, Louis; Sheppard, Harold, Econonic Eailure: Alienation and Extremism, An Azbor University of Michigan Press, 1968 .

25. Davoj, Stephen H.; Reimanis, Gunars, "The Role of Anomie as a Psychological Concept," Journal of Individual Psychology. Vol. $1.5, \mathrm{No} .2$, November 1959, pp $2.15-225$.

26. Dirkhein. Endle, Suicide: A Study in Seciology, Tcans. By John A. Spaulding and Goorge Simpson, The Free Press, New York, 1056. 
27. Clinard, B. Marshal1. "The Theoretical Implications of Anonie and Deviant Behavior," from Anonie and Deviant Behavior: A Discussion and Critique, ed. by Mirshall B. Clinard, Free Fress of Glencoe, Collier-Macmillan Limited, London, 1964.

28. Propper, Martin M.; Kiaune, Virginia; Murray, John B., "The Alienation Syndrone among Male Aciolescents in Prestige Catholic and Public High Schools," Psychological Reports, Vo1. 27, 1970. FP 311-315.

29. Horney, Karen, The Neurotic Personality of Our Time, W. W. Norton $\&$ Company, New York, $19 \overline{37}$.

30. Davids, Anthony, "Sone Comments on Ansbacher's Note on the "Alienation Syndrome' and Adlex's Concept of 'Distance," Journal of Consulting Psychology, Vol. 20, No. 6, December 1956, pp 485-486.

31. Ansbacher, Heinz L., "Anomie, the Sociologists Conception of Lack of Social Interest," Journal of Individual Psychology. Vol. 15, No. 2, Novernber, 1959, pp 212-2.4.

32. Abstracts for Social Workers, National Association of Social Workers, New York.

33. Encyclopedia of Social Work, Robert Morris, Edicor-in-Cuier, National Association of Social Workers, New York, 1971.

34. Holits, Florence, Caserrork, a Psycho-sccial Therapy, Randon House, 1964.

35. Perlman, Helen H., Social Casework: A Problem-solving Process, The University of Chicago Pross, 1957 .

36. Gold Martin, "Juvenile Delinquency as a Symptom of Alienation," Journa1 of Social Issues, Vol. 25, No. 2, 1969, pp 12J-135.

37. Adler, Nathan, "The Antimomian Pexsonality: The Hippie Character Type," Psychiatry, Vo1. 31, 1To. 4, J.968, pp 325-338.

38. Josselyn, Irene M., The Adolescent and His World, Famj.y Service Association of America, New York, 1952 .

39. Coleman, James S., "Adolescent Subculture and Academic Achievement," from Mental Health and Achievement. ed. by E. Paul Torrance and Robert D. Stron, John Wiley \& Sons, Inc., New York, 1965.

40. "genson Rolytechnic Bigh School," a pamphlet produced by the Berson Tolytedmlo itgh School Graphic Arte Department, porrianó, uregon. 
41. Dorn, Dean S., "Self-Concept, Alienation, and Anxlety in a. Contraculture and Subculture; A Research Report," The Journal of Criminal Law, Criminology and Polfce Science, Vol. 59, No. 4, 1958, pp 531-535.

42. Bernstein, Sau1, "Alienated Youth," Federa1 Probation, Vo1. 33, No. 2, 1969, pp 3-10.

43. Beil, Wende11, "Anomie, Social Isolation, and Class Structure," Sociometry, Vo1. 20, No, 2, 1957, pp 105-116.

44. Gould, Laurence J.s "Conformity and Marginality: Two Faces of Alienation," Journal of Social Issues, VoI. 25, No. 2, pp 39-63, 1969.

45. Klein. Edvard B.; Gould, Laurence J., "Alienation and Ióentification in College Women," Journal. of Personality, Vol. 37 , No. 3, September, 1969. 
APPENDIX A

BENSON POTYTECHNIC HIGH SCHOOL

Benson High School, in addition to offering a regular high school. program, offers a large number of courses in which a student can acquire working technical skills. The technical course offerings are as follows:

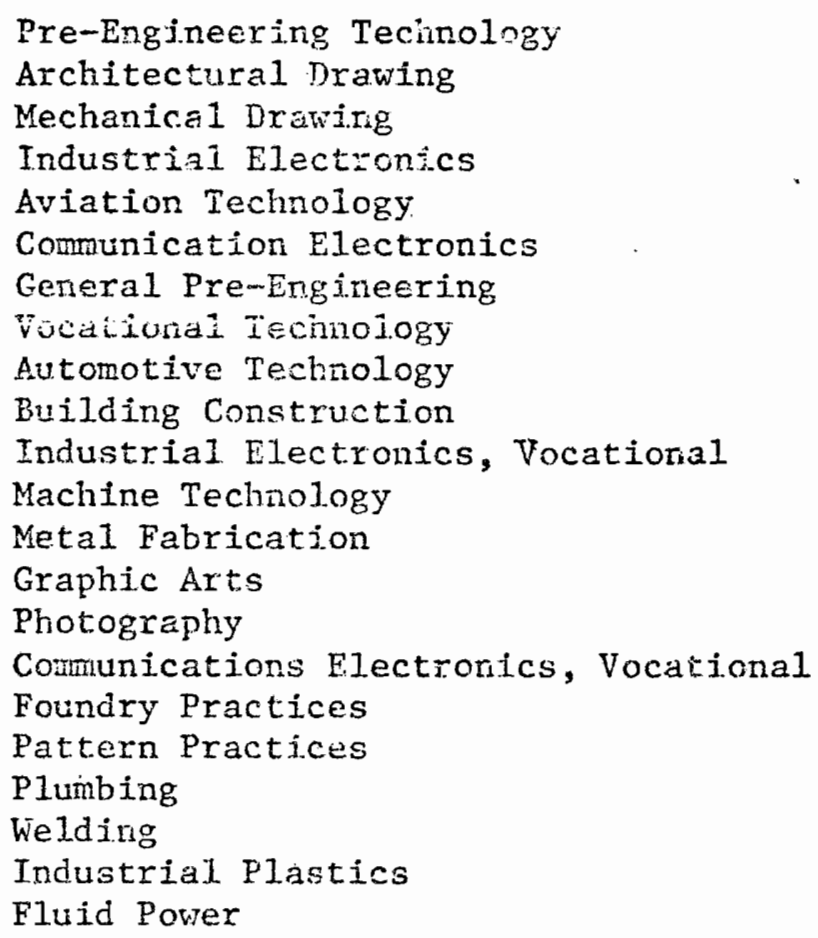

Although the school emphasizes technical training, students who attend Benson are not limited by that fact in theix choices of career. Most prepare themselves for skilled jobs on graduation. However, about $38 \%$ go on to careers requiring attendance at two and four year colleges. Others go into the armed forces on graduation. 
The school employs a full-time job placement counselor, who, with the aid of vocational teachers, keeps abreast of the job market and helps students to find jobs or to enter apprenticeship programs commensurate with the skills they have acquired at Benson. Job placement counseling is offered to graduates as a life-time service. Benson's record of placement of graduates in further schocling, the armed forces, or in jobs has been $100 \%$ for several years.

Students enter the Benson program by submitting an application for acceptance to the program. Their interests and apptitudes, as well as their records of tardies, absences, and suspensions are weighed by school personnel who must decide whether to accept or reject the applicant. Severe discipline problems cause some students to be rejected. If a student wishes to drop out of Benson, he may negotiate to return to the high school serving the district of his residence. 


\section{APPENDIX B \\ THE MULTIPLE ALIEANATION NEASURE \\ AS MODIFIED BY WRITER}

\section{OPINION SURVEY}

On these flages are twenty statements of opinions about the world we live in. It has been found that some people agree with all of these statentents, some agxee with rone of them, and some agree with part of them. Whatever you feel about these statements, you can be sure that there are nany who share your views.

Folloving each statement there are listed six possible resporses as foliows:

strongly__dgree not sure but not sure but__isagree strongly
sgree

Pledse place a check mark $(v)$ in the blask following the response that states bsst your feeling about the statement. For example, if you are rot sure 'uer you feel about a statement, but think you disagree, you would place the check mark as shown in the sample above.

Renemier, alciough the statements may seem alike in some ways, they are different. Flease consider each statenent separately and mark a respunse for each one, yet wcrk as rapidly as you can.

Alsc, do not put your name on these pages. Your responses to these statements are confidential.

I. People will do aimost anything if the rewax is nigh enough.

Strongly agree not sure but not sure but disagree strongly agree may agree may not agree disagree

2. Most peovie don't realize how wuch their lives are controlled by plota nothet in secret places.

strongly agree not sure but not sure but disagree strongly
agree

3. In epite of what sone people say, the lot of the average man is Settinis wese. 
strong $1 y$ agree not sure but may agree. not suce but may not agree strongly disagree

4. Success is more dependent on luck than raal ability. strongly _ agree not sure but not sure but__ disagree strongly agree may agree may not agree disagree

5. There is littie use in witing to public officials because they aren't really interested in the problems of the average man.

strongly_agree__not sure but__ not sure but disagree__ strongly
agree

6. It is usually best to te1l your superiors and bosses what they really want to hear.

strongly_._agree_not sure but_not sure but_disagree strongiy
agree

7. Ideas that have no useful or practical application are of litele use to man.

strongly agree not sure but: not sure but disagree strong $1 y^{\prime}$ ä́ries mäy agrex tiäy tiut agi is

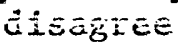

8. Things are changing so fast these days that one doesn't know what to expect from day to day.

strongly agree_ not sure but not sure but agree may agree may not agree disagree strongly disagree

9. Nowadays a person has to live pretty much for today and let tomorrow take care of itself.

strongiy e.gree agree not sure but may agree. not sure but nay not agree disagree strong $1 \mathrm{y}$ disagree

10. Otr contry has too beny poor people who cen do littje to raise their slandari of living.

strongly agree not sure but not sure but disagree strongly
agree

11. Iew peopla really look forwarc to ihejx work.

strongly agrec_not sure but_not sure but_disagree_strongly
agree




\section{APPENDIX C \\ FACULTY QUESTIONNAIRE}

Three categories of benavior are listed beiow, and each category contains four descriptive statements. You. wi1] have a numbered Iist of Students whose numbers correspond to the numbers given below the categories.

Please select, for each, student, one statement from each category that best describes that student's behavior in school to the best of your knowledge. Place the symbols of the resuiting three statements to the right of the student's number in the sane order as the behavior categories.

If you feel you have no knowledge of a scudent's benavior with respect to any category, please enter a check $(\checkmark)$ mark in place of a statement symbol.

I. Involvement in Activities

1. This student is involved in extra-curricular activities but not in sports.

2. This student is involved in sportis as his only type of extracurricular activity.

3. This student is involved in sports and other extra-curricular activities.

4. This student is not involved in sports or extra-curricular activities.

II. Academic: Approach

A. This student participates weIl in class discussion and group projects, but does not do well on individual assignments and projects.

B. Ihis student does weI1 on individual assignments and projects but does not do weII in class discussion and group projects.

C. This student does well at both fri classrcom discussion and group projects and individuai assignments and projects. 
D. This student does not do well at either Individual assigninents and projects or classroom discussion and group projects.

III. Conduct.

W. This student is always we11 behaved.

X. This student has been a discipline problem that has been handled entirely in class.

Y. This student has been a discipline problem and has been asked to leave the classrocn and may have been suspendsd once.

2. This student has been a discipline problem and has been suspended more than once.

\section{RESPONSE SHEET}
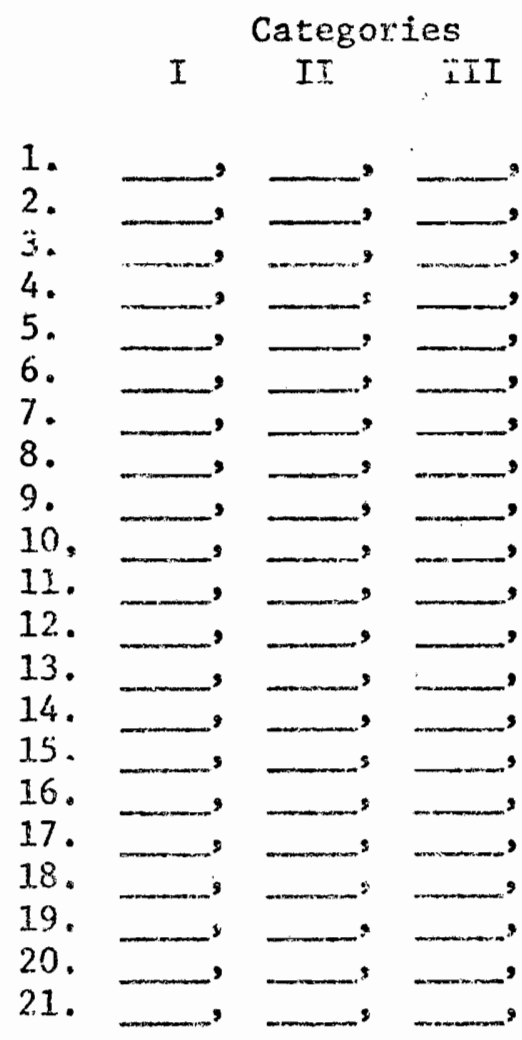

22.

23.

24.

25 .

26 .

27 .

28.

29.

30 .

31.

32.

33.

34.

35 .

36 .

37 .

38 .

39 .

40.

41 .

42.
Categories

II.

III

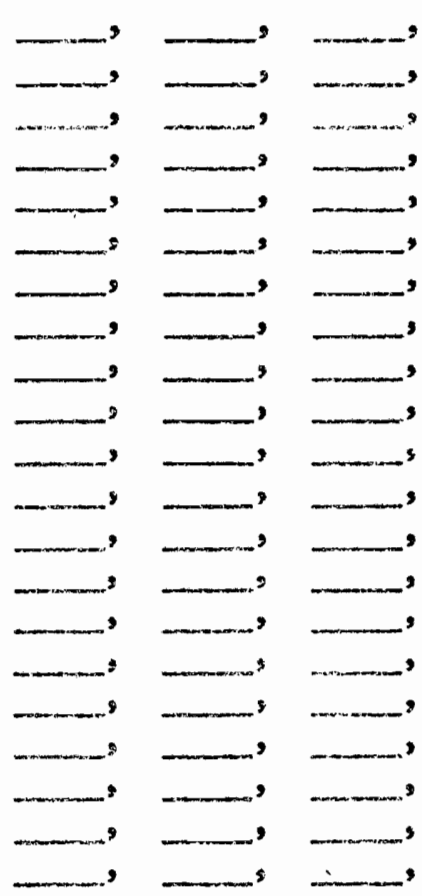

